\title{
Technology translation and synthesis:
}

\section{A conceptual framework for critiquing determinism in the development project}

\author{
By \\ Rebecca Paxton
}

A Thesis Submitted to the Victoria University of Wellington in Partial Fulfilment of the Requirements for the Degree of Master of International Relations (MIR)

School of History, Philosophy, Political Science and International Relations

Victoria University of Wellington 2010 


\section{ABSTRACT}

This thesis constructs a theoretical framework which critiques the legitimacy of technology transfer for the purposes of development. Under the auspices of the development project, technology transfer has involved the introduction of technology into so-called developing societies in the hope of leapfrogging them toward modernity. This process embodies a deterministic definition of technology that sees it as an inherently objective and rational process, mapping the ideas of Western science. Hence, all technological and social change is expected to follow a linear progression from pre-modern to modern, and developing to developed, respectively.

In contrast, philosophers of technology have argued that technology has a cultural dimension which permits multiple avenues of change. This definition incorporates a dialogue between technology and society, whereby technologies are reinterpreted and imbued with culturally specific meanings by the adopting societies. The culturally contingent nature of these meanings entails that they are not necessarily transferable between cultures. Rather, technology must be translated. Conceptually, technology translation requires that aspects of the donor and recipient cultures are intertwined, producing a novel set of hybridised meanings. I argue that this process occurs primarily through the mode of synthesis - an emergent process whose outcomes are not predictable based solely on a priori knowledge of the interacting cultures.

These ideas are tested in case studies arising from Indian agriculture. Indian agriculture has a long history of external agricultural influence in the shape of European colonialism, the Green Revolution and the more recent Gene Revolution. The results support the idea that both technology transfer and synthesis have occurred in Indian agriculture following the adoption of new technologies. Development agencies must revise their simplistic notion of technology by acknowledging the centrality of culture as part of technology, therefore, if they wish to ensure greater success in the future. 
TABLE OF CONTENTS

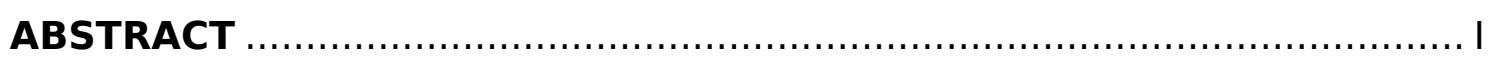

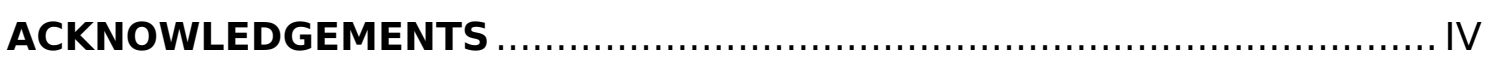

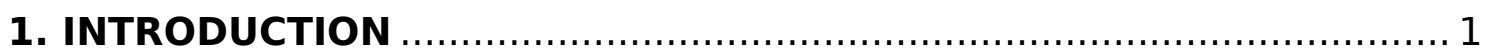

1.1. Development and technology ................................................ 2

1.2. Technology translation and its effects ...................................... 4

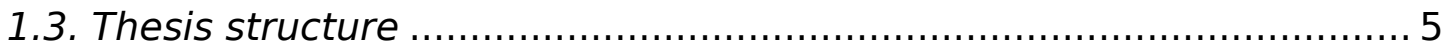

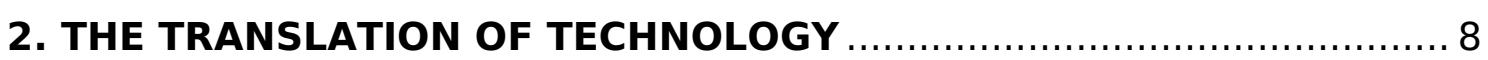

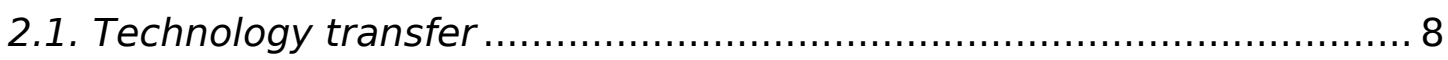

2.2. Technology as artefacts ............................................. 11

2.3. The relationship between technology and science ...................... 14

2.4. Questioning science as pure reason ....................................... 16

2.5. Re-envisioning technological trajectories .............................. 19

2.6. Technology as a social construction ..................................... 21

2.7. The limits of technology transfer ..................................... 24

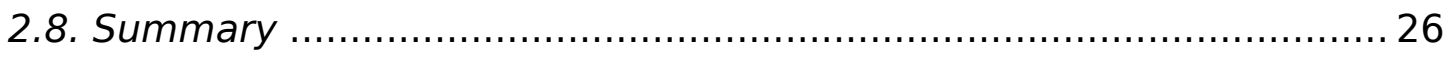

3. TECHNOLOGY ADOPTION AND HYBRIDISATION ..................... 27

3.1. Culture and knowledge systems ........................................ 28

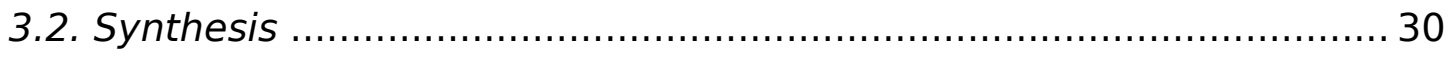

3.3. The incommensurability of cultural knowledge .......................... 33

3.4. Technological imperialism and power................................. 37

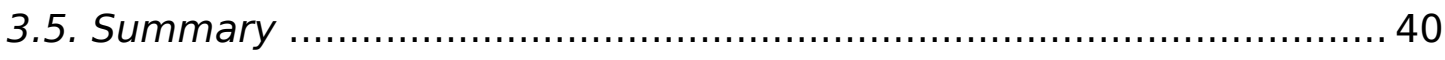

4. EVIDENCE OF TECHNOLOGY TRANSLATION AND SYNTHESIS $\ldots \ldots . .42$

4.1. What constitutes evidence for technology translation? ................... 42

4.2. Technology translation in Indian agriculture .............................. 43

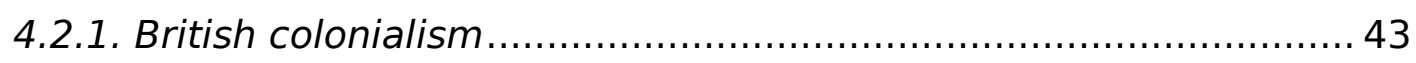

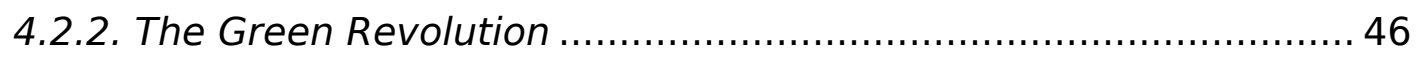


4.3. The Green Revolution and humoral agronomy ............................ 53

4.4. The Gene Revolution and India's agricultural IPR policy .................. 56

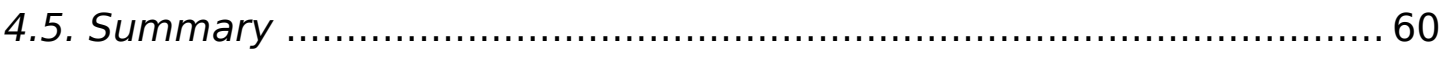

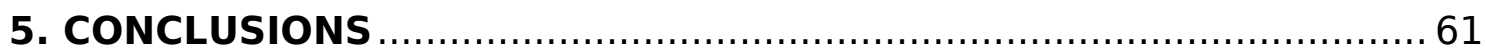

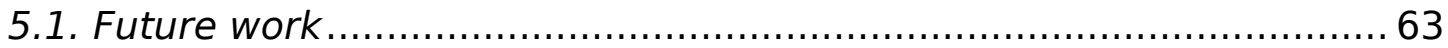

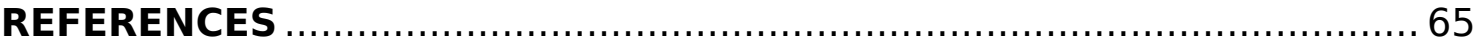

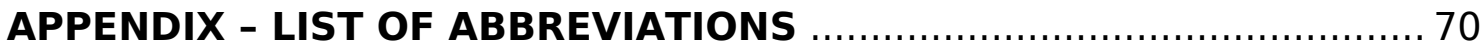




\section{ACKNOWLEDGEMENTS}

I would like to gratefully acknowledge my supervisor Ben Thirkell-White who, aside from his invaluable academic insights, has faithfully promised to enlist the help and luck of the Cornish pixies - bribing them with a glass of milk to ensure the success of this thesis. Furthermore, I must thank the academic and administrative staff of the VUW International Relations department, especially MIR coordinator Robbie Shilliam and Robert Deuchars who have both broadened my IR horizons immeasurably. I would also like to thank Jay Shaw for sharing his insights into Indian culture and society, which I could not have gained from the literature alone. To my MIR classmates I offer thanks for the stimulating discussions and crazy ideas of world domination. I also owe a big thanks to my partner Ray Tobler who always inspires me to work harder and enjoy the academic process. Finally, many thanks to the VUW Scholarships Committee for their financial support, without which I could not have undertaken this programme. 
Introduction

\section{INTRODUCTION}

The deterministic view of culture, where different cultural entities can be placed on a linear scale from savage to civilised, has a long history in the humanities and social sciences. Historically, one of the key yardsticks by which cultural progress was measured has been the level of technological development. This idea is particularly well exemplified by agents of the development project. Both supporters and critics of the development project agree that the adoption of Western technology into non-Western societies supplants local cultural knowledge and practices. Indeed the telos of development requires that this be the case. Technology transfer has, therefore, been an important tool in the development project and a popular target for protest by local populations and post-development academics.

An alternative to this deterministic view of social and technological change is one which sees technology as part of a wider social system and imbued with culturally specific meanings. This means that technology is not culturally neutral, and nor is culture technologically neutral. The two are mutually constitutive such that the adoption of non-local technology results in the hybridisation of social systems. In this view technology cannot be transferred wholesale, because the culturally embedded meanings that define technology are not inherent properties of the technological artefact or process. Rather, the adoption of new technologies leads to a synthesis between the donor and recipient cultures producing something more akin to translation than transfer.

Agents of the development project have, however, failed to recognise the socially constructed properties of technology and its role within the adoption of new innovations. This oversight stems from a lack of attention to the conceptual difficulties in defining technology that have been raised by

philosophers of technology. Consequently, the transfer of technology is considered a mere logistical exercise within the development discourse and its failures have not been associated with its conceptual problems. To understand the reasons for this oversight, one must first understand the particular international climate that existed following the Second World War and in which the development project was conceived. 
Introduction

\subsection{Development and technology}

The period following the Second World War saw the simultaneous reconstruction and rearrangement of the political and economic relationships of the Western states. In this uncertain climate independence long sought by many of the colonies of Africa and Asia was gained, introducing a new set of participants in the international system. While these new nation-states were able to participate in the international system as independent actors, they did not do so on an equal footing with European and North American states ${ }^{1}$. The perception that in part fuelled colonialism of a culturally, socially, politically and economically superior West remained. Judged upon heavy reliance upon agriculture rather than industry, low productivity, and health, literacy and education indicators, Non-Western States were seen as existing in stages of development prior to modernity ${ }^{2}$. Thus, the newly independent nation-states were classified upon a continuum, not from savage to civilized, but from underdeveloped to developed.

The association in the West of technology with science has been important in this classification process. Science since the Renaissance has been increasingly seen in the West as 'the' source of objective knowledge allowing humankind to transcend nature's limitations. Technology has been identified as both a product of rational scientific discovery and as a means of gaining further scientific knowledge by replacing and improving the fallible senses. In this perspective technology is seen as universally valid, its use and meaning determined by reason, and is subsequently considered culturally neutral and universally relevant. It is from this relationship that the deterministic trajectory of technological change adopted by the development discourse is derived. Thus, the rhetoric of the development project positions Western technology as a fundamental mode of development.

${ }^{1}$ G Rist, The History of Development: From Western Origins to Global Faith (Zed Books, 2002).

2 Pierre de Senarclens, "How the United Nations Promotes Development through Technical Assistance," in The Post-Development Reader, ed. M Rahnema and V Bawtree (Zed Books London, 1998). p. 193 
Introduction

This belief in social progress towards the Western ideal has also been used to justify the interventions of international institutions, and Western government and non-governmental organisations into the sovereign affairs of 'developing' states ${ }^{3}$. Their rhetoric proposes that

"[W]ith a few temporary deviations, all societies are advancing naturally and consistently 'up' on a route from poverty, barbarism, despotism and ignorance to riches, civilization, democracy, and rationality, the highest expression of which is science" ${ }^{4}$.

The Economic and Social Council (ECOSOC) and the UN General Assembly emphasised in particular the need to create within these states a "rationalist and materialistic culture, the values and educational norms that favour the progress of science and technology" ${ }^{2}$.

Implicit in defining the industrialised and urbanised West as the epitome of modernity, agriculture and rurality has come to embody the traditional via its juxtaposition. As Varshney has put it:

"If a high proportion of the net domestic product is dependent on agriculture and if a large proportion of its labour force is employed on farms, then the nation-state is pronounced to be afflicted with the malady of "underdevelopment." ${ }^{6}$

Hence, agricultural societies have been targeted as being in particular need of development. Consequently, agricultural technology has been transferred from the West to the non-West in order to achieve this end. This is expected to reduce hunger, ensure political stability in the populous rural areas of the developing world and, critically, support urbanisation and industrial development ${ }^{7}$.

${ }^{3}$ Rist, The History of Development: From Western Origins to Global Faith.

4 Teodor Shanin, "The Idea of Progress," in The Post-Development Reader, ed. M Rahnema and V Bawtree (Zed Books London, 1998).

5 Senarclens, "How the United Nations Promotes Development through Technical Assistance." p. 193

${ }^{6}$ Ashutosh Varshney, Democracy, Development, and the Countryside: Rural-Urban Struggles in India. New York: Cambridge University Press (1995) quoted in A Gupta, Postcolonial Developments: Agriculture in the Making of Modern India (Duke Univ Pr, 1998). p. 38

${ }^{7}$ lbid. 


\subsection{Technology translation and its effects}

Technology transfer has been an important tool in the development project's mandate to bring the Western socio-economic model to so-called developing countries. Development agencies, supported by Western and non-Western governments, have attempted to expedite the modernisation of developing countries by the replacement of local technologies with their more 'advanced' Western counterparts ${ }^{8}$. Following technology transfer, it is assumed that the local social, political and economic milieu of developing states will begin to converge upon the Western ideal, irrespective of the local cultural setting.

The ensuing changes have, however, typically failed to conform to the Western archetype and often diverge markedly from expectations. Despite disappointments in the levels of modernisation achieved after decades of technology transfer, examinations of how to improve technology transfer have tended to treat it as a purely logistical exercise. The conceptual basis of technology transfer, e.g. the definitions of technology and its role in social change, has, however, remained largely unexamined in the development discourse.

In contrast, the conceptual foundations of technology have been subject to continuous revision by philosophers of technology. Practitioners of the philosophy of technology (PT) are mainly drawn from two camps: the applied technology fields (specifically engineering) and philosophers within the humanities. Although the definitions adopted by the two camps have often conflicted, there exists an awareness of the inherent difficulty of pinpointing technology's relationship to society. This awareness has not, however, resulted in a dialogue between the development and PT disciplines. This appears to be due to the shared misconception that these conceptual difficulties do not have bearing on the practical realities of the innovation and adoption of technology.

The failure of states to converge upon Western model, therefore, can be viewed as resulting from conceptual weaknesses rather than methodological or logistical factors. By not addressing the conceptual complexities of technology outlined by philosophers of technology, the development discourse has maintained a doggedly deterministic

\footnotetext{
${ }^{8}$ Rist, The History of Development: From Western Origins to Global Faith.
} 
perspective. Alternative definitions of technology, meanwhile, see it as part of a wider social system with culturally constructed meanings, and contest claims that Western science and technology are objective and universal. Because meaning is culturally contingent it cannot be regarded as transferrable, and it is more useful to consider cross-cultural technology adoption as a process of translation. This perspective envisions socioeconomic and technological change as an open ended process that has multiple potential trajectories rather than an unyielding process having a single predefined trajectory. Local culture is not supplanted following the adoption of Western technologies; instead new meanings emerge at the interface between cultures, invoking a form of cultural hybridisation.

Although cultural hybridisation has been raised by many authors, particularly in the postcolonial tradition, the mode of hybridisation remains unexplored. Technology translation precludes hybridisation in the form of coexistence, i.e. Western and non-Western culture existing side by side with no interaction ${ }^{9}$. Alternative forms of hybridisation are additive hybridisation, i.e. a new unified technology is created from the combining of the two cultures, and synthesis whereby the interaction of cultures has emergent outcomes. While neither of these forms of hybridisation permits social and technological change to strictly follow the Western model, the new and unexpected characteristics of the latter mean that technological change is essentially non-deterministic and unpredictable.

\subsection{Thesis structure}

This thesis articulates the problems inherent in the concept of technology transfer as a mode of development. In particular, it examines the problems that are brought to light from a shift in the conceptual framework that informs. In doing so it brings together two disciplines which, although closely connected by subject matter, have so far failed to meet conceptually: the mainstream development discourse and the philosophy of technology.

\footnotetext{
9 'Interaction' here, and throughout the rest of the text, has its common usage, that is: two or more parties acting together. When referring to the mathematical form of interaction, i.e. deviations from strict linearity, I have used the word emergence.
} 
Introduction

The main argument of this thesis is presented in three chapters followed by a concluding chapter. In the first chapter I draw upon the philosophy of technology literature to show that the way in which technology is defined has implications for whether technology can truly be considered as transferrable between cultures. Recent developments in this literature suggest that it is necessary to define technologies as socially constructed systems imbued with multiple culturally constituted meanings. Because these meanings are culturally specific, I suggest that technologies are non-transferrable and instead propose that technology is translated between cultures. That is, the adopted technology is given new meanings that are defined within the culture into which it is introduced. I have termed this process 'technology translation'.

The second chapter examines how the process of hybridisation takes place within the context of technology translation. I propose that synthesis is a useful concept for this purpose. Synthesis is defined herein as the interaction of cultures from which an emergent change ensues. The concept of emergence has only recently been used in the social sciences and humanities, and provides a useful and powerful means of framing cultural synthesis. Central to this perspective is that synthesis is identified as being both irreversible and incompatible with the notion of progress adopted by the development discourse. Furthermore, when viewed in this light synthesis illuminates problems within the post-development literature, by critiquing the notion of technological imperialism and the threat posed to 'authentic' non-Western traditions by the adoption of Western technology. In doing so I show that both the supporters and critics of development neglect an important middle ground where the agency of the recipient society is acknowledged and where the power of the Western development model is not deterministic. This form of cultural hybridity is inconceivable under current conceptualisations of technology in the development discourse and will remain so until it and the philosophy of technology are reconciled.

Chapter three presents a historical overview of technology translation in Indian agriculture and two case studies on synthesis drawn from the subcontinent. While understanding the role of culture as an influence in technology translation and synthesis suffers from a lack of dedicated analyses, the abundance of both cultural and agricultural studies on India make it an ideal candidate to begin to build a picture of how these 
processes unfold. The first case study presents the synthesis that took place between Green Revolution (GR) technologies and the concept of humoral agronomy. Humoral agronomy refers to the balancing of hot, cold, dry and moist elements which ensure health in both people and crops. This balance depends upon both the inherent constitution of the organism and its inputs. Synthesis is evidenced by the association of the delicate and demanding constitution of GR seeds with fragile health, greed and moral corruption in those who produce or eat GR crops. Thus, a new set of social relations emerged from the adoption of GR technologies. Whereas the first case study refers to synthesis at the grassroots level amongst farmers and rural communities, the second case study shows synthesis taking place within Indian government legislation over the adoption of genetically modified (GM) technologies in agriculture. The Indian Plant Varieties and Farmers' Rights Bill introduced private intellectual property rights over GM technologies required by international agreements. In a unique move it also granted property rights over so-called landraces - crop varieties bred by Indian farmers - and privileges to farmers over varieties covered by the act. These riders were previously unseen in similar acts in Western and nonWestern states and indicates a unique interaction between the social and economic realities of Indian agriculture and international legal stipulations. 


\section{THE TRANSLATION OF TECHNOLOGY}

This chapter challenges the deterministic version of technological progress that is entrenched within the mainstream development discourse. This view is grounded in the belief in an objective and scientific form of technological innovation and the notion of progress. The concept of 'technology translation' is introduced to replace 'technology transfer', the idea that has historically been employed within development discourse. The key difference between the two concepts is that the former includes culturally constituted meanings to define technology, a practice that is absent in the latter. This absence has resulted in technology transfer being approached as a culturally neutral act in the development discourse. This subsequently permits a single trajectory of technological development to be imagined, specifically movement towards the Western ideal.

\subsection{Technology transfer}

Senarclens argues that

"no issue turned up more frequently in the work of the United Nations this is still the case today - than the ability of science and technology to leapfrog over the classic stages from backwardness to development" ${ }^{10}$.

Such a simple perspective of technology transfer has lead to the similarly straightforward assumption of it being a purely logistical process that obviates the need for comprehending its conceptual aspects. For instance, the UN Food and Agricultural Organisation (FAO) consider technology transfer to be:

“...a process encompassing various elements: (i) hardware (equipment, tools, machines, varieties, breeds, vaccines, etc.); (ii) technique (knowhow, [...] software procedures, agronomic practices); (iii) “human ware" (knowledge, education, attitude, ability); (iv) organization [...] ([...] institutional establishment, management); (v) the final output or

10 Senarclens, "How the United Nations Promotes Development through Technical Assistance." p. 193 
product that sets the direction and the level of effort, including marketing strategies, needed by the four other components." ${ }^{11}$.

Disappointment with the lack of modernisation achieved after decades of technology transfer have prompted discussions about how the process of development, as a logistical exercise, can be improved ${ }^{12}$. Studies have been undertaken on how technology is adopted, and proposed solutions have centred upon possible methodological changes such as a greater participation of recipient communities in determining the appropriateness of technological innovations. For instance, there has been increasing acknowledgement amongst development agencies that education, marketing and other organisational structures must accompany new innovations. This realisation that technology encompasses more than just mere objects and processes with practical applicability has spiked interest in local and indigenous cultures and their role in the uptake of modern technology. Consequently, a lack scientific understanding within the developing societies has been blamed for preventing them from maximising the productive use of their resources. However, this view still fails to acknowledge that locals may privilege their own forms of knowledge and innovation above others ${ }^{13}$. Behind this interpretation lies the assumption one ascribed to by many Western philosophers throughout history - that what is based upon reason is self-evident and accessible to every human due to their inherently rational human nature ${ }^{14}$.

Such efforts to better manage technology transfer amount to a refinement of the practical details of the transfer process. For example, one response has been to establish the appropriate 'level' of technology to transfer which depends on the degree of scientific sophistication of the recipient society' ${ }^{\prime 15}$. However, whether the definition of technology utilised by development agencies has had an influence on the outcomes of technology transfer has not yet been addressed. Indeed, the conceptual

\footnotetext{
11

FAO, $\quad$ "Technology

for

Agriculture

(Online),"

http://www.fao.org/teca/content/terms-dictionaries-and-fao-publications.

12 AO Hirschman, "The Rise and Decline of Development Economics," Essays in Trespassing: Economics to Politics and Beyond 1 (1981), Rist, The History of Development: From Western Origins to Global Faith.

${ }_{13}^{13}$ Rist, The History of Development: From Western Origins to Global Faith.

14 Ibid.

15 Arturo Escobar, "The Making and Unmaking of the Third World through Development," in The Post-Development Reader, ed. M Rahnema and V Bawtree (Zed Books London, 1998).
} 
aspects of technology are far from unproblematic. Broad public debate continues regarding their application and effects upon society, while analyses concerning these matters have tended to be overlooked. Consequently, questions about whether technology can be seen as an embodiment of an objective and culturally neutral science, to legitimacy of the non-scientific foundations of technologies, and the role of technology and culture in mutually constituting one another, remain unexplored in the development discourse.

In short, the agents of the development project have largely failed to acknowledge the uncertainties and ambiguities in their definition of technology and technological change. In contrast to the development discourse, these ideas have been widely debated by philosophers of technology. However, they have remained trapped within the discipline and sheltered from public debate. Accordingly, technology transfer has taken place without due recognition of the philosophical issues raised within the philosophy of technology concerning the relationship between technology and society. Arguably, this situation arose through a lack of dialogue between the two main branches of the philosophy of technology; that emerging from the humanities and that from the engineering and technology industry (which Mitcham calls the Humanities Philosophy of Technology, HPT, and the Engineering Philosophy of Technology, EPT, respectively). While it generally ignores the conceptual aspects of technology, the development discourse has a closer affinity to the EPT discourse, which has a more technocratic outlook, than that of the HPT, which emphasises the cultural and social aspects of technology. Additionally, the HPT discourse does not target the community of engineers who produce technological innovations or the development experts who disseminate technology ${ }^{16}$, which may have also contributed to this situation.

In a sense, the international development project has become wedged between the EPT and HPT. The development project has, through its role in the dissemination of Western technology, adopted technocratic notions of technological progress which benefit of mankind. At the same

\footnotetext{
${ }^{16}$ Maarten Franssen, Gert-Jan Lokhorst, and Ibo van de Poel, "Stanford Encyclopedia of Philosophy: Technology (Online) at Http://Plato.Stanford.Edu/Entries/Technology/ ", C Mitcham, Thinking through Technology: The Path between Engineering and Philosophy (University of Chicago Press, 1994).
} 
time it has been plagued by the types of social and cultural problems that are examined by the HPT. More acutely, technology transfer has become increasingly undertaken by private companies that have no mandate to consider the flawed idea of social and economic development ${ }^{17}$. Benefitting from the pro-market approach to development that has become dominant in the $20^{\text {th }}$ century, these companies are now arguably more influential than the dedicated development agencies. The chances that the philosophical considerations of technology outlined above will be addressed in a meaningful way by the development discourse seem, therefore, to be dwindling.

To understand the problems confronting technology transfer by mainstream development agencies, therefore, one must first examine how they have understood and come to define technology. The explanations of technology by development agencies, as well as those of technology innovators, social scientists and philosophers, are explored in the following section.

\subsection{Technology as artefacts}

Many development agencies do not provide an explicit definition of technology in their published and online materials. The FAO's Technology for Agriculture group is a notable exception and defines technology as "practices or techniques, tools or equipment, know-how and skills, or combinations of the aforementioned components." 18 . This definition conforms to what Slack and Wise consider to be the most common popular usage of the term: as 'things' with 'practical applications' ${ }^{19}$. As objects that can be precisely delimited, such as a tractor or a hybrid seed, technologies can easily be transferred as discrete 'entities'. Similarly, a process, procedure or skill set, with a given set of rules, can be transferred in the form of a manual or through education and apprenticeship.

While this definition of technology has a long history, this history is replete with philosophical challenges. One challenge concerns the nature of 'practical applications', i.e. utility, and whether this is objectively or socially

\footnotetext{
17 WE Murray, Geographies of Globalization (Routledge, 2006).

${ }^{18} \mathrm{FAO}$, "Technology for Agriculture (Online)."

19 JD Slack and JM Wise, Culture + Technology: A Primer (New York: Peter Lang, 2005). p. 95
} 
defined. In the tradition of Socrates, Plato and Aristotle, human will could be based upon either pure reason or practical experience, with the former having superiority ${ }^{20}$. Because pure reason supposedly allowed one to 'see' the true objects as opposed to their representations as mediated by the senses, it was attributed with having universal validity. A clear distinction was made between the philosophical and the technical, with only the former allowing humanity to gain understanding of objective truth. The technical was considered a more lowly pursuit, following which it was reasonable to suppose that the creation of artefacts would be guided by the latter. This suggests that by defining technology as the objects and processes - i.e. artefacts - created and maintained by humankind, technological innovations are guided by the specific practical aims and needs of their inventors and are henceforth social objects and processes. Therefore, there is a need to consider the social construction of technology even when adopting such a seemingly uncomplicated definition of technology.

A corollary to this definition of technology, with its roots in practical experience rather than pure reason, has technology mimicking nature rather than transcending our experiences. This was the predominant perception of technology during the time of the Ancient Greeks and the Roman Empire ${ }^{21}$. This view also resurfaced at the turn of the $20^{\text {th }}$ century, in Cassirer's suggestion that technology was an extension of human organs e.g. a spade is an extension of the hand, communications networks are extensions of the nervous system, and so $\mathrm{on}^{22}$. If technology does imitate nature, then technological development is likely to have an expression that is defined by local ecologies, and subsequently differ for societies living in different natural settings. Hence, even when considering technology as being wholly informed by nature, there is no reason to suppose that technological change should follow a single trajectory everywhere (this is of course unless nature is itself uniform everywhere, which seems inconceivable when thinking of the range of ecotypes occupied by humans historically).

\footnotetext{
${ }^{20}$ RC Scharff and V Dusek, Philosophy of Technology: The Technological Condition: An Anthology (Blackwell, 2003).

${ }^{21}$ Franssen, Lokhorst, and Poel, "Stanford Encyclopedia of Philosophy: Technology (Online) at Http://Plato.Stanford.Edu/Entries/Technology/".

22 Mitcham, Thinking through Technology: The Path between Engineering and Philosophy.
} 
Defining technology as hardware or processes with practical applications, therefore, does not automatically negate the importance of the social, cultural, and environmental contexts in which these technologies operate $^{23}$. If we understand technological innovation to be the product of practical experience rather than pure reason, then it will necessarily have social influences. Not only can the technologies themselves be perceived as socially constructed, but the utility they serve is also the product of human relationships and relationships between humans and their environments. Thus, in moving technologies into new social and environmental contexts, technologies may lose their practical utility and their incumbent definitions may no longer apply.

The problems inherent in the definition of technology as an artefact devised purely from practical experience and imitating nature has seen it wane in influence since the Renaissance. A contrasting understanding of technology sees it as the result of 'true' innovation - i.e., a creation of the intellect - that transcends nature's limitations. In this view technology comprises natural objects and processes that are transformed by humans into those with novel forms and functions for human utility. That is, the inventor can transform a "cave into home, stone into weapons, uranium into atomic bomb"24. The Spanish philosopher Juan David García Bacca proposed that such technological innovation represents a "humanization of the historical, intellectual, and social worlds" ${ }^{25}$. By inventing new technology, humans are creating entirely new objects - objects without prior existence in nature or basis in experience. As pseudo-divine creators, humankind does not need to refer to nature or a transcendental plane in order to know what an artefact is. In creating it, humankind has given it 'Being'.

Overall, both arguments do not provide any explicit basis for why technological change should be considered as a deterministic process. In the former case differences in the natural environments are expected to lead to the production of different technologies, and in the latter case the transformation of natural objects into artefacts calls for the creation of new meanings. It follows that technology consists of artefacts with specific

\footnotetext{
${ }^{23}$ Slack and Wise, Culture + Technology: A Primer.

24 Mitcham, Thinking through Technology: The Path between Engineering and Philosophy. p. 36

${ }^{25}$ Ibid. p. 34
} 
meanings that are not innate, but consigned to them by their makers. As a result, the definition of technology as artefacts with practical utility clearly omits an important component of technology; its meaning. The association of technology with specific meanings has important implications that I will return to later in this chapter.

\subsection{The relationship between technology and science}

The Renaissance oversaw a shift in perception of technological innovation from being the product of practical experience to that of pure reason. During this period there was a "marriage of metaphysics and technology"26 which had not previously existed. In particular, there was a new appreciation for the role of technology in gaining higher-level knowledge when combined with the rapidly evolving scientific method ${ }^{27}$. This has, at various times, led technology to be superficially defined as applied science and, conversely, as theoretical technology ${ }^{28}$. Neither of these definitions is currently given much weight in philosophical examinations of technology, but they are still common in non-academic discourse ${ }^{29}$. Regardless of ontological having a role in enabling priority, since the Renaissance technology has been identified as enabling humankind to transcend the subjective knowledge supplied by the senses and gain objective knowledge of Reality as outlined by the Ancient Greek philosophers.

Historically, Western science has been characterised by attempts to situate science wholly within an objective, empirical realm, i.e. Plato's realm of 'truth'. For example, the logical positivist turn in science in the early 1900 s held that only claims verifiable by empirical evidence or logical reasoning were valid, and further presented this as a unique feature of Western science ${ }^{30}$. Similarly (though from the opposing stance), Popper

\footnotetext{
26 Agassi 1981 quoted in V Dusek, Philosophy of Technology: An Introduction (Blackwell Pub, 2006). p. 12

27 Franssen, Lokhorst, and Poel, "Stanford Encyclopedia of Philosophy: Technology (Online) at Http://Plato.Stanford.Edu/Entries/Technology/ ".

28 MR Alvarez, "Modern Technology and Technological Determinism: The Empire Strikes Again," Bulletin of Science, Technology \& Society 19, no. 5 (1999), Mitcham, Thinking through Technology: The Path between Engineering and Philosophy, M Bunge, "Technology as Applied Science," Technology and Culture 7, no. 3 (1966).

29 Slack and Wise, Culture + Technology: A Primer, R Kline, "Construing" Technology" As" Applied Science": Public Rhetoric of Scientists and Engineers in the United States, 1880-1945," Isis 86, no. 2 (1995).

30 Dusek, Philosophy of Technology: An Introduction.
} 
prescribed the scientific method as discarding hypotheses that cannot be supported by repeatable empirical evidence, thereby ostensibly freeing scientific knowledge from subjective bias ${ }^{31}$. Thus, science lays claim to the production of universal validity of objective laws and facts, albeit facts deduced from experience. If science could achieve such an end, then its status would be as a source, or rather the source, of universally valid knowledge about reality. Technology is regarded as being vital in this task, as instruments are required to replace and improve the fallible human senses.

The ontological status of the scientific 'fact' has itself been the subject of much debate in the philosophy of science ${ }^{32}$. Logical positivism, as well as Popper's scientific method, presupposes that there is a pre-existing Reality from which science can glean facts or laws. These are not created by the scientist, but discovered through the scientific process, which is considered to be free from the input of social, religious or cultural metaphysics. Similarly, Friedrich Dessauer, in the Kantian tradition, perceived technology as having an immanent reality in the same manner as the scientific fact. Dessauer proposed that technological innovations are not innovations at all, but the application of ideas that have a real existence prior to human discovery in a transcendental realm ${ }^{33}$. For Dessauer, it is through the "inner working out" of technological ideas that humankind is able to transcend to a Platonic/Kantian realm of "things-in-themselves" 34 . Thus, rather than being linked to practical knowledge as was suggested by Plato (although at the time this included science), science is connected to pure reason and is granted a greater degree of objectivity and universality accordingly.

This depiction of science and technology as ontological bedfellows, underpins the deterministic trajectory of technological change accepted by

\footnotetext{
${ }^{31}$ KR Popper, The Logic of Scientific Discovery (Hutchinson, 1959), KR Popper and P Camiller, All Life Is Problem Solving (Routledge, 1999).

32 L Soler, "Are the Results of Our Science Contingent or Inevitable?," Studies in History and Philosophy of Science (2008). Also see RN Giere, Scientific Perspectivism (University of Chicago Press, 2006), I Hacking, The Social Construction of What? (Harvard Univ Pr, 1999), - - - "How Inevitable Are the Results of Successful Science?," Philosophy of Science 67, no. 3 (2000).

33 TJ Rivers, "An Introduction to the Metaphysics of Technology," Technology in Society 27, no. 4 (2005).

34 Mitcham, Thinking through Technology: The Path between Engineering and Philosophy. p. $32 \&$ p. 32
} 
the development discourse. Technology, defined as either the conjoined twin of a universally valid science or as a set of ideas waiting to be made manifest, changes along a single trajectory that is predetermined by the underlying nature of reality ${ }^{35}$. In this sense, technology is thought to undergo a discernable progression that maps the advancement of scientific knowledge within each society. Consequently, artefacts with practical utility that have no basis in science are not considered technology at all. This disqualifies many religious and ritualistic objects as well as a vast array of artefacts that are derived from 'indigenous' knowledge.

This definition allows the transfer of technology to take place from technologically advanced - or developed - societies, to less technologically advanced - or developing - societies. Accordingly, the transfer of technology is unproblematic as it merely enables its recipients to leapfrog the innovative process and to take advantage of the discoveries already made by other societies. Moreover, because the meanings associated with technology are objective and culturally neutral, they too can be transferred by investing in suitable forms of scientific education in the recipient societies. Relating technology to science in such a way provides a persuasive argument for technology transfer and provides the theoretical basis for modernisation and the development project itself ${ }^{36}$.

\subsection{Questioning science as pure reason}

The definition outlined in the previous section, which underpins the mainstream development discourse, has been the subject of strong criticism. For instance, it is debatable whether technological innovation is attributable to pure reason rather than practical knowledge for two reasons. Firstly, the relationship between science and technology is not beyond scrutiny. Nandy argues that the notion of modern technology and science being 'inextricably linked' is a myth, and that technological innovations have had their basis in prior technologies rather than scientific discoveries ${ }^{37}$. A study by the U.S. Defence department showed that technological

${ }^{35}$ A Feenberg, Critical Theory of Technology (Oxford University Press New York, NY, 1991).

36 Ibid.

37 A Nandy, Traditions, Tyranny, and Utopias: Essays in the Politics of Awareness (Oxford University Press, USA, 1987). p. 77 
development relied predominantly upon engineering research and design and experience from missions rather than upon scientific discovery. This was supported by a later British study ${ }^{38}$.

Others have emphasised the role of chance in the discovery of new technologies. For instance, Louis Pasteur noted that "fortune favours the prepared mind" pointing out that while scientific research may enable humankind to more easily recognise useful artefacts and processes, these are often not those one set out to discover ${ }^{39}$. Indeed, modern science is a relatively young discipline, with both logical positivism and Popper's falsification criterion having been conceived in the $20^{\text {th }}$ century. Hence, it cannot possibly account for a large number of technological innovations that precede its jurisdiction. Tools and processes with practical applications existed long before to the establishment of modern science and a number of these - brought to Europe from China, India, the Middle East and elsewhere - were the inspiration for many later scientific discoveries in the West ${ }^{40}$. If these are not to be considered technologies, then the status European artefacts wrought from them also become questionable.

Secondly, it is necessary to query whether an objective Reality exists and, if so, whether pure reason or rationality has the power to reveal it. What is distinctive about modernity, according to a post-structuralist view held by Heidegger, is precisely the belief that rationality can be used to understand the nature of Reality ${ }^{41}$. Starting from the assumption that the basis of reality is "a self-contained system of motion of units of mass related spatio-temporally"42, modern scientists suppose that Reality can be revealed through the rational examination of objects. However, such a starting point relies upon certain things being "stipulated in advance as already known" ${ }^{\prime 3}$. This requirement hinders science from being able to completely explore reality, as it is ultimately delimited by the a priori assumption of what is knowable. Hence, Heidegger's modern individual

\footnotetext{
38 TJ Pinch and WE Bijker, "The Social Construction of Facts and Artefacts: Or How the Sociology of Science and the Sociology of Technology Might Benefit Each Other," Social studies of Science 14, no. 3 (1984).

39 Dusek, Philosophy of Technology: An Introduction. p. 35

40 Slack and Wise, Culture + Technology: A Primer.

41 GB Smith, "Heidegger, Technology and Postmodernity," The Social Science Journal 28, no. 3 (1991).

42 Heidegger "Age" quoted in Ibid. p. 373

43 Ibid. p. 373
} 
subjectively limits what can be Real, and in assuming universal rationality, does so for all humanity.

The universality and objectivity of science itself has also been the subject of dispute ${ }^{44}$. Additionally, Thomas Kuhn argued that science itself undergoes periods of paradigmatic limitations upon the scope and content of its research ${ }^{45}$. These limitations are often added to by practical considerations such as the political and funding climates, which restrict the viability of certain research areas and topics. Marcuse also saw Western science being dominated by political and economic interests and suggested that an alternative form of science and technology be established that gives voice to those marginalised within the dominant science regime ${ }^{46}$. Additionally, claims that modern science is endemic only to the West or, even more narrowly, to overt scientific environments such as the laboratory, further challenge the notion of a universal science ${ }^{47}$.

Importantly, the practical and philosophical problems created in defining technology as artefacts with practical applications are not criticisisms of Western science and technology in and of itself. Indeed, Western technological innovations have proved extremely useful in a number of human enterprises and will no doubt continue to be so. Rather, this section seeks to question the objectivity and concomitant universality that is often ascribed, or at least tacitly assumed, to be inherent to science and technology. It is this supposed universality that ultimately justifies the development discourse, including the transfer of technology to aid technological advancement in so-called pre-modern societies, that I wish to draw attention to here.

\footnotetext{
44 See SG Harding, Is Science Multicultural?: Postcolonialisms, Feminisms, and Epistemologies (Indiana Univ Pr, 1998).

${ }_{45}$ Dusek, Philosophy of Technology: An Introduction.

46 Mitcham, Thinking through Technology: The Path between Engineering and Philosophy. p. 87

47 I Hacking, "The Self-Vindication of the Laboratory Sciences," Science as practice and culture 65 (1992), A Pickering, "From Science as Knowledge to Science as Practice," Science as practice and culture (1992).
} 


\title{
2.5. Re-envisioning technological trajectories
}

In contrast to the idea of technology as objects or processes, philosophers of technology have tended to characterise technology as an activity. ${ }^{48}$. For instance, Joseph Pitt defined technology as "humanity at work" 49 , while Gilbert Ryle has said that technology is not about 'knowing that', but rather 'knowing how'50. Both of these statements capture the inherently active nature of technology. Technology does not objectively describe or explain as is the purpose of science - it is a normative pursuit of 'what should be'. That is, it is embedded within a set of social values about how the world might be better. This normative aspect of technology makes room for disagreement about the preferred direction of technological change and thus highlights its political and often contingent nature.

Many of the theories of technological innovation cited above, such as that of Dessaur, belong to the EPT tradition. For such philosophers, the act of making technology is what makes humans as a species unique in nature. Moreover, through the creation of technology humanity is able to know reality and, ultimately, break free from the limitations of nature. In the HPT tradition, however, technology gains its activity primarily through the process of its interpretation. For instance, for HPT theorist Lewis Mumford it is not the ability to make, but to combine "a wide variety of animal propensities into an emergent cultural entity" ${ }^{\prime 51}$ particularly through the ability to interpret and give symbolic meaning, which defines the human species. He suggested that:

\begin{abstract}
"If all the mechanical inventions of the last five thousand years were suddenly wiped away, there would be a catastrophic loss of life; but man would still be human. But if one took away the function of interpretation, ... the whole round earth would fade away more swiftly than Prospero's vision [and] man would sink into a more helpless and brutish state than any animal; close to paralysis" 52 .
\end{abstract}

\footnotetext{
48 Mitcham, Thinking through Technology: The Path between Engineering and Philosophy.

49 Franssen, Lokhorst, and Poel, "Stanford Encyclopedia of Philosophy: Technology (Online) at Http://Plato.Stanford.Edu/Entries/Technology/ ". ${ }_{50} \mathrm{lbid}$.

$51 \mathrm{~L}$ Mumford, The Myth of the Machine: Technics and Human Development (Harcourt Brace Jovanovich, 1967). p. 5

52 Mitcham, Thinking through Technology: The Path between Engineering and Philosophy. p. 43
} 
Thus, for Mumford and others like him it is this symbolic and cultural dimension of technology which is of key importance. Under this logic the same artefact may, for two different people, have very different meanings.

In Mumford's estimation, technology is not a determinant of human development, nor is it mainly utilitarian as held by several other EPT philosophers. Rather, technology is an outlet for the capacity of the inventor to think and interpret, in order to fulfil his or her "superorganic demands and aspirations" ${ }^{\prime 53}$. Because technological innovations are responses to these demands, such as economic gain or political power, the technological change is neither necessarily inevitable nor socially beneficial. Indeed, Mumfords view is symptomatic of the more dimly held view of technology within the HPT relative to the EPT.

An implication of Mumford's views is that technological change is not necessarily linear or deterministic as 'interpretation' entails the possibility of multiple paths. That science and technology in many non-Western societies have not shared the close relationship that has been a feature of the postRenaissance West provides evidence for this non-linearity. Nandy notes that for Hindu societies in particular, the artisans that produced technology never achieved the same social status as the Brahmans engaged with "interpretation of the macro- and micro-cosmos of nature" ${ }^{54}$. He notes a similar distinction between science and technology in Persia, Egypt and China, with technology consistently devalued compared to science. Nor have many non-Western societies undergone the conflict of science and metaphysics that occurred in Europe between philosophers of science and the Christian church ${ }^{55}$. Again, Nandy notes that technologists in the context of a more metaphysical non-Western science have attempted to imbue spirituality and attach deities to their innovations to increase their legitimacy and validate their work ${ }^{56}$.

A common ground shared by both the EPT and HPT traditions is the utilitarian perception of technology. Technological knowledge is not seen as an aim in itself, but as a means to an end. This idea is well captured by German philosopher and engineer Peter Engelmeier, who conceived of

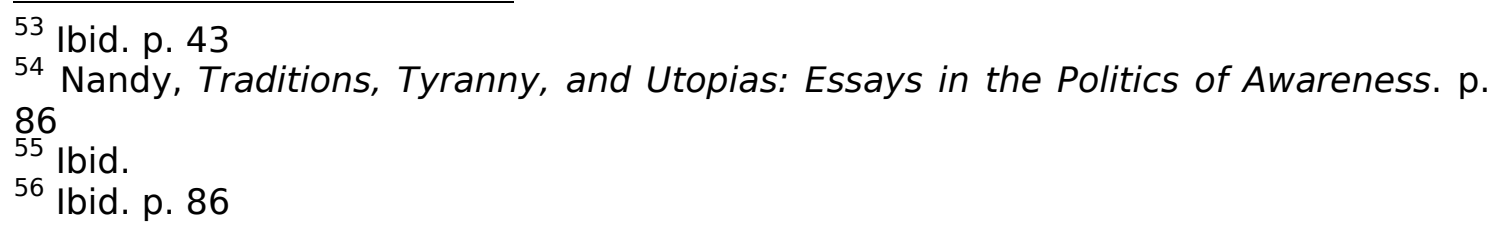


technology as "the innermost idea of all purposeful action which springs from the utilitarian drives" ${ }^{\prime 57}$. The exact utility of technology, however, varies amongst philosophers. French philosopher Jacques Ellul saw the dominant purpose of technology as maximising efficiency ${ }^{58}$, while the American mathematics teacher and philosopher Timothy Walker held the purpose of 'mechanical philosophy' was to free mankind in "both thought and practice" $" 59$. The development discourse has made appeals to both of these goals, but in practice appears more aligned with the ideas of Ellul ${ }^{60}$.

Finally, for many thinkers in the philosophy of technology, technology does not have a universal utility that is shared by all humanity. For instance, Ortega y Gasset claims that there are "as many different kinds of technics as there are human projects" ${ }^{\prime 61}$. For Ortega y Gasset a relationship exists between the subjective needs and desires of each individual and the adoption and innovation of technology. His consideration of what it is to be human and our relationship to technology led him to express that "Yo soy yo y mi circunstancia"62 - I am I plus my circumstances. This view is clearly at odds with that implied in mainstream development discourse. If the utility of a technology cannot be said to have universal validity, then technology itself cannot be assumed to be transferrable in the deterministic, uni-linear sense intended by development agencies.

\subsection{Technology as a social construction}

The perception that technology is a key determinant of social development, but socio-cultural factors do not determine how technology progresses, is an implicitly held assumption in the development dialogue. The idea that science and technology are social constructions, therefore, directly

\footnotetext{
57 Engelmeier quoted in Mitcham, Thinking through Technology: The Path between Engineering and Philosophy. p.27

58 Franssen, Lokhorst, and Poel, "Stanford Encyclopedia of Philosophy: Technology (Online) at Http://Plato.Stanford.Edu/Entries/Technology/ ", J Ellul, The Technological Society (Knopf Books for Young Readers, 1964), J Ellul and J Neugroschel, The Technological System (Citeseer, 1980).

59 Walker quoted in Mitcham, Thinking through Technology: The Path between Engineering and Philosophy. p. 20

60 Escobar, "The Making and Unmaking of the Third World through Development.", Shanin, "The Idea of Progress."

61 Mitcham, Thinking through Technology: The Path between Engineering and Philosophy. p. 47

62 Ibid. p. 46
} 
challenges this view. This idea rejects the notion that scientific knowledge is epistemologically unique, thus resisting science's claim to objectivity and universal validity ${ }^{63}$. From this perspective scientific knowledge is no different from so-called pre-modern or primitive cultures. Furthermore, the perceived universality of Western scientific knowledge is explicable as a Western bias toward these explanations. An example of this bias is found in Cohen, whereby the refusal to adopt certain Genetically Modified (GM) crops by the local populations and politicians was assumed to be based on political and religious sentiments, while the acceptance of other GM crops was explained as the result of scientific persuasion and economic rationality $^{64}$. A central thrust of the social constructivist argument is that there should be symmetry in the explanations offered for both scientific and non-scientific beliefs, thereby taking an unbiased approach to the truth or falsehood of such beliefs ${ }^{65}$.

In considering technology to be shaped by society, social constructivists argue that 'relevant social groups' influence the innovation process by the meanings they attach to an artefact. Dusek suggests that it may only be feasible to speak of technology "in the context of the people who use it, maintain it, and repair it" ${ }^{\prime 66}$. I would suggest that this relevance also be extended to the intended recipients who by choice or circumstance do not end up using the technology. This is because the act of rejection can still impart meaning to a technology. For instance, rejection of a technology amongst certain social groups can lead to it having negative and contested meanings within that society. This was the case upon the introduction of the bicycle in the Victorian era United Kingdom, where the negative views held across a wide array of social groups lead to its slow adoption and mixed regard $^{67}$.

The relevance of technology used by members of different cultures, therefore, is ultimately dependent upon the meanings they ascribe to it.

63 Pinch and Bijker, "The Social Construction of Facts and Artefacts: Or How the Sociology of Science and the Sociology of Technology Might Benefit Each Other." p. 401

$64 \mathrm{JI}$ Cohen and R Paarlberg, "Unlocking Crop Biotechnology in Developing Countries--a Report from the Field," World Development 32, no. 9 (2004).

65 Pinch and Bijker, "The Social Construction of Facts and Artefacts: Or How the Sociology of Science and the Sociology of Technology Might Benefit Each Other."

66 Dusek, Philosophy of Technology: An Introduction. p. 33

67 Pinch and Bijker, "The Social Construction of Facts and Artefacts: Or How the Sociology of Science and the Sociology of Technology Might Benefit Each Other." 
Similarly, technological change depends upon not only how these changes address the problems or needs of a society, but how technology fits within the culture ${ }^{68}$. Thus, it is recognised that not only technical considerations are important in the adoption of a new technology, but ethical, economic, political and religious considerations may be equally, and in many cases more, important.

In the view of social constructivists, technology cannot be seen as being clearly defined and distinct from either science or society. Rather, these are interlinked and exist in a system that comprises the artefact, and its 'knowing' and 'doing', each of which are inherently social phenomena ${ }^{69}$. As a system there are flows between the acts of innovation, production, use, and disposal of objects and processes. Hence, technology does not merely comprise tangible hardware and processes, but also the language used to describe it, the concepts and world view within which it is situated and the purpose or practical application it is to perform. In other words, the definition of technology as a system necessarily includes the meaning that it has in society. It is suggested that a technology and its utility can only be described in reference to a collective knowledge system. That is, it is from culture that technology takes its meanings.

There is, therefore, no reason to believe that technology (or science for that matter) changes along a single trajectory as maintained in the development discourse. Like science itself, the success or failure of a technology within a certain society should be examined symmetrically. The social constructivist authors Pinch and Bijker contended that this process was not taking place, however. They argued that studies of failed technological innovations were being ignored, imparting the impression that

“...the whole history of technological development had followed an orderly or rational path, as though today's world was the precise goal toward which all decisions, made since the beginning of history, were consciously directed." ${ }^{70}$.

For social constructivists technological change constitutes an open-ended, unpredictable process, rather than a deterministic progression toward a rational ideal. The telos of the development process is thereby incompatible

\footnotetext{
${ }^{68}$ Ibid.

${ }_{70}^{6} \mathrm{lbid}$.

70 Eugene Ferguson (1974) quoted in Ibid.
} 
with these socially constructed, culturally contingent views of technology. It is this definition of technology that is adopted and examined in this study.

\subsection{The limits of technology transfer}

The conclusion that technology becomes embedded in society by the construction of culturally contingent meanings has important implications for the development project. For some, defining technology as a system that necessarily comprises cultural meanings is akin to technological relativism, i.e., technology only has meaning within a local context. In this view, Western technology is made irrelevant to non-Western societies just as many non-Western technologies are considered irrelevant to the West today. However, this is not the position taken here. Rather, I build upon Nandy's position that the universal relevance of technology needs to be stressed $^{71}$, albeit a universality that entails plurality. Indeed, Western technologies can be, and have been, useful in a non-Western context (and vice versa). However, because they are imbued with meanings which are culturally contingent, they cannot be transferred.

Although technologies cannot be transferred between cultures, it is evident that the adoption of new technologies frequently takes place - i.e. technology does travel ${ }^{72}$. In place of technology transfer, therefore, I argue that technologies are translated as they move from one cultural context to another. As Mitcham points out; "Translation, even of the most sophisticated sort, tends to leave a residue of untranslated and untranslatable meaning"73. For instance, Chakrabarty argues that the assumption that the translation of the English word water into the Hindi word pani conveys the same meaning is problematic. Furthermore, he suggests while science has introduced an ostensibly objective definition to mediate between the two imprecise words - in this case coining the term $\mathrm{H}_{2} \mathrm{O}$ - which this also assumes that the meaning of both other terms can be assimilated into the scientific term. This suggests that it is not possible to bundle meanings, derived from the entire history of cultural and intellectual experiences of a society, into an artefact. Meanings are not simply restricted to identifying the object itself, but contain historical and cultural information that are not

\footnotetext{
${ }^{71}$ Nandy, Traditions, Tyranny, and Utopias: Essays in the Politics of Awareness.

72 W Anderson, "Introduction: Postcolonial Technoscience," Social studies of Science (2002).

73 Mitcham, Thinking through Technology: The Path between Engineering and Philosophy. p. 64
} 
self-evident in the object. Thus, meanings do not transfer, and must be constructed upon receipt of the object or process. The adoption of new technologies is accompanied by their embedding within a pre-existing culture. Western social and physical science, as well as development and humanitarian projects have, therefore, been continuously engaged in translations in their interactions with non-Western cultures (as well as internally, as 'the West' is not homogenous in language or culture).

This point is also raised by Shiva in her examination of Western agricultural and forestry practices, and, implicitly, by Netting in the study of agricultural labour. Both argue that non-Western concepts of agriculture, forestry and labour are imbued with a meaning that is not held by Western development experts or expressed within the development discourse ${ }^{74}$. For instance, the introduction of Western forestry practices only considered the commercial benefit of a single crop in a single form. That is, the ideal forest for Western forestry consists of a single tree variety that is harvested for its wood. All other parts of the tree; its leaves and smaller branches, are considered waste, while other plants and animals are seen as weeds or pests. This ignores the food and fuel producing capacity of the forest that is greatly valued by many Indian cultures who do not clearly distinguish between the functions of agriculture and forestry. Because of this, what forestry has considered the 'normal' forest, i.e. the single crop plantation, is not considered as being a forest at all by many local peoples ${ }^{75}$.

I do, however, disagree with an assertion made by Shiva that differences in meaning necessarily make non-Western and Western technologies incommensurable. Nandy points out that Western medical practices that have been "fitted within traditional conceptions of health ... have enriched the traditions and given them a new resilience" ${ }^{\prime 76}$. What I suggest, therefore, is not a static and inflexible geography of technologies, with each technology being coterminous with the culture in which it has arisen, but rather a fluid network of exchange, inspiration and hybridisation. This is to say that improvements to adopted technologies can occur when

\footnotetext{
74 RMC Netting, Smallholders, Householders: Farm Families and the Ecology of Intensive, Sustainable Agriculture (Stanford Univ Pr, 1993), V Shiva, Monocultures of the Mind (Third World Network, 1993).

${ }^{75}$ Shiva, Monocultures of the Mind. pp. 22-27

${ }^{76}$ Nandy, Traditions, Tyranny, and Utopias: Essays in the Politics of Awareness. p. 90
} 
measured within the requirements of the recipient culture, without this being amounting to a deterministic process.

\subsection{Summary}

This chapter has argued that the legitimacy of technology transfer for the purposes of development has relied upon a definition of technology as a product of universal and objective facts based in Western science. It calls into question the universality of science and the concomitant springboard effect that is expected to propel non-Western recipient cultures into modernity. It is evident that initiatives such as 'appropriate' and 'intermediate technology' transfer, which rely upon this particular concept of progress, are problematic if one accepts that technology has a cultural dimension which permits multiple avenues of change. The development project needs to implement an updated definition of technology that incorporates the cultural dialogue that takes between the artefact and society. Because this process necessarily involves the interpretation within a new cultural context, it is considered to be more akin to translation than transfer. This does not automatically imply that Western innovations are only useful within the West. On the contrary, it proposes that translation imbues new meanings to the technological artefact, allowing a new technology to be born. 


\section{TECHNOLOGY ADOPTION AND HYBRIDISATION}

In adopting translation in the place of transfer as the dominant mode of technology introduction brings with it several important new ideas. One important concern is that while technology transfer permits Western technology to supplant or exist alongside, but separate from, non-Western cultures, technology translation does not. This is because the socially constructed meanings that help define a technology are not directly transferrable, with new meanings being reinstated by the recipient culture. Consequently, introduced technologies become part of the socio-cultural milieu of the recipient society, including their culture. Instead of existing side by side with local culture and technology, therefore, Western innovations are localised and become part of the recipient society, meaning they are no longer Western within this context.

The argument offered here is not the direct opposite of technological determinism, i.e. technological change via social determinism, but rather that technology cannot be disentangled from society. The two are indelibly linked; the needs of a society give rise to new technologies, and similarly, technology stimulates new needs within society. Furthermore, technology relies upon and demands that certain conditions be present, which can cause adaptations in other parts of the social system. In order for the adopted technology to function within its new cultural context, changes in pre-existing divisions of labour, natural resource use, or types of infrastructure may be required. It is reasonable to expect that societies and technologies are mutually responsive, therefore, requiring that neither one be explicitly cast in the role of prime mover.

This localisation of meaning, interaction and effects is described as a form of cultural hybridisation within the postcolonial and post-development literature ${ }^{77}$. However, the mode of hybridisation is rarely addressed. In this

\footnotetext{
77 See SB Brodt, "Interactions of Formal and Informal Knowledge Systems in VillageBased Tree Management in Central India," Agriculture and Human Values 16, no. 4 (1999), Gupta, Postcolonial Developments: Agriculture in the Making of Modern India, Nandy, Traditions, Tyranny, and Utopias: Essays in the Politics of Awareness, R Kurin, "Indigenous Agronomics and Agricultural Development in the Indus Basin," Human organization 42, no. 4 (1983), AR Vasavi, "'Hybrid Times, Hybrid People': Culture and Agriculture in South India," Man (1994).
} 
chapter I introduce the concept of synthesis as a mode of hybridisation and the theoretical framework for its activity.

\subsection{Culture and knowledge systems}

The majority of studies of technology adoption in developing countries emphasise what Steers et al. call the "artifactual component" of technology, i.e. technical details of new innovations and their suitability for performing specific tasks. These aspects, while not culturally neutral in a historical sense, are not culturally malleable. For instance, a car will need tyres and petrol to operate, and this does not change unless the fundamental artefactual nature of the car is itself changed. Meanwhile, adoption studies have tended to neglect the "axiological components (values, cultures, and worldviews)" of those same technologies ${ }^{78}$. These two sets of components correspond to what Habermas conceives of as two broad categories of interests in social life. These help to constitute cultural knowledge and subsequently form the basis of innovation and meaning. Firstly, there are the 'technical interests', which provide the need for knowledge that "generalizes, predicts, and allows control"79, and correspond to the artifactual components. Secondly, Habermas describes "practical interests in maintaining the intersubjectivity allowing the reproduction of people's capability to order their socio-cultural world"80, corresponding to the axiological components. These interests constitute what Habermas calls the "historical-hermeneutic sciences" and seek to "expand mutual understanding between people" ${ }^{\prime \prime 1}$. Such practical interests help form traditions and culture, giving individuals a common way of interpreting the world.

Both these components are referred to here under the umbrella term 'knowledge system'. The knowledge system of a particular society is localised, not necessarily spatially, but in the relationships between people

\footnotetext{
${ }^{78}$ Richard M Steers, Alan D Meyer, and CJ Sanchez-Runde, "National Culture and the Adoption of New Technologies," Journal of world business 43, no. 3 (2008). pp. 256 \& 257

79 A Bebbington, "Indigenous Agricultural Knowledge Systems, Human Interests, and Critical Analysis: Reflections on Farmer Organization in Ecuador," Agriculture and Human Values 8, no. 1 (1991). P. 15

${ }^{80}$ White (1989) quoted in Ibid. p. 15

${ }^{81}$ Ibid. p. 15
} 
who share an ability to interact and a similarity of context ${ }^{82}$. At the most basic level, each individual has his/her own knowledge system, i.e. he or she has access to a variety of specific information and organises, interprets and understands - makes sense of - this information in a unique way. Thus, by their very nature knowledge systems are products of the social relationships and contexts experienced by each individual. When a knowledge system gains a collective character - i.e. when the information and method of making sense of it becomes shared within a given spatio-temporal locality it can be described as culture ${ }^{83}$. For the purposes of this study it is useful to think of knowledge systems as being separate entities, although what demarcates different systems is not easily imagined. Here I borrow the language of social systems theory, and consider knowledge systems as clusters of individual nodes situated within a larger continuous network, with lower degrees of connection between individuals from different clusters than within clusters ${ }^{84}$.

Social constructivists emphasise that the meaning a technology acquires is pre-existent within the recipient culture prior to its introduction. In other words, technology is "embedded in the cultural psychology and psycho-ecology of a community" ${ }^{85}$. As Winner points out, most of the changes to everyday life brought about by the adoption of new technology are recognisable as versions of prior patterns ${ }^{86}$. In agriculture synthetic fertilisers replace a variety of natural animal and plant fertilisers, tractors replace oxen and the hand plough, and high yielding varieties (HYV) of plants replace existing varieties. Hence, although the technological artefact is new, there exists an immediately perceivable link with pre-existing technologies - a space into which this new technology is fit. For most technologies it is questionable, therefore, if their novelty is fundamental or merely technical. Fundamental change would consist of adding

\footnotetext{
82 A Appadurai, "The Production of Locality," Counterworks: Managing the diversity of knowledge (1995).

$83 \mathrm{U}$ Hannerz, Cultural Complexity: Studies in the Social Organization of Meaning (Columbia Univ Pr, 1992).

${ }^{84}$ W Buckley, Sociology and Modern Systems Theory (Prentice-Hall Englewood Cliffs, NJ, 1967).

${ }^{85}$ Nandy, Traditions, Tyranny, and Utopias: Essays in the Politics of Awareness. p. 91

${ }^{86} \mathrm{H}$ Jonas, "Toward a Philosophy of Technology," The Hastings Center Report 9, no. 1 (1979), Langdon Winner, "Technologies as Forms of Life," in Readings in the Philosophy of Technology, ed. DM Kaplan (Rowman \& Littlefield, 2004). p. 109
} 
"fundamentally new activities" "87 to the human repertoire. Even with regard to a technology as controversial as recombinant DNA techniques, its novelty is unclear not only to the public, but also to the industry form where technology originates. Novelty has been pursued in order to gain intellectual property rights, while links to pre-existing technology and 'substantial equivalence' to available food stuffs have been emphasised to argue the safety of GM crops $^{88}$.

Hence, it is reasonable to assume that fundamentally new technologies will be difficult, or even impossible, to translate. In contrast, technologies which have some antecedent within the recipient culture should allow for new meanings to be generated. This is not to say that such technologies will then necessarily be adopted, however. The new technology may acquire a wholly negative meaning in this new cultural context, leading to it being unanimously rejected. While the technology will not become incorporated within the recipient economic system in this case, it will always have been translated. Indeed, the act of translation is necessary before any decisions regarding the technology can be reached. The nature of posttransfer cultural hybridisation, specifically through the process of synthesis, is explored in the next section.

\subsection{Synthesis}

The concept of synthesis is employed here to explain how the process of cultural hybridisation takes place. The term 'synthesis' denotes that elements from each interacting culture are combined to produce an emergent outcome. The emergent property entails that what is created is not the sum of its component parts, such that these changes are not predictable based upon the characteristics of the introduced technology or the recipient and donor cultures. ${ }^{89}$. Consequently, synthesis defies the understanding of cultural and technological change as being a universal and linear processes. Rather, the results of the interactions are inherently

\footnotetext{
87 Winner, "Technologies as Forms of Life." p. 109

$88 \mathrm{~S}$ Sahai, "Indigenous Knowledge and Its Protection in India," Trading in knowledge: development perspectives on TRIPS, trade, and sustainability (2003), Esther J. Kok and Harry A. Kuiper, "Comparative Safety Assessment for Biotech Crops," Trends in Biotechnology 21, no. 10 (2003).

${ }^{89}$ HJ Morowitz, The Emergence of Everything: How the World Became Complex (New York: Oxford University Press 2002).
} 
unpredictable - there is no way of guessing the outcome even with perfect knowledge of all participating elements. Alternatively, an 'additive' process of hybridisation is defined as producing an outcome that is predicable upon the knowledge of the participating elements. While possible in theory, its existence in reality is dubious, given the attendant complexities involved in the process of hybridisation.

I suggest that synthesis first occurs at the point of translation, whence aspects of the donor and recipient culture initially become entwined. It is at this point that the culturally embedded meaning of a technology is first constructed. The cultural entwinement is informed by the space of relevance for the technology within each of culture. The space of relevance may differ between the donor and recipient societies, as they are a socio-cultural feature than an aspect of technology. Accordingly, this overlap does not entail perfect symmetry between the interacting cultures. The continued presence of the technology in the recipient society will maintain the cultural interface. Hence, over time further spaces of relevance will arise within the recipient culture and inform the meanings of the technology.

For instance, for agriculturalists a space of relevance exists that includes the need to clear, plough and rotate the soil. Following its introduction, the tractor will take some of its meaning in the recipient culture through its link with this space of relevance. Additionally, a limited knowledge of and faith in mechanics, reliance upon the availability of petroleum based fuels, and an expectation of transport infrastructure may be introduced to the culture by the presence of the tractor. Yet the use of the machinery, its role in social relations (e.g. the form of ownership, norms surrounding its use), even the explanations for how it operates may be strongly anchored in the local culture. As Chakrabarty notes, deities are ascribed to tools and machines in India, thus instilling a unique and local spiritual relevance to them that may not exist in other cultures ${ }^{90}$. Furthermore, the effects of technology adoption may not be evident at the time of adoption, and the decision to take up or forgo new ideas is, therefore, not always conscious.

90 D Chakrabarty, Provincializing Europe: Postcolonial Thought and Historical Difference (Princeton Univ Pr, 2000). 
While the consequences of adopting a new technology may be wide ranging, the ensuing synthesis need not directly affect all aspects of a culture. Brodt describes how, within systems theory, collective knowledge systems consist of nested levels of abstraction. The 'primary level' consists of the "pieces of information" including relationships of cause-and-effect" ${ }^{91}$. In agriculture such information might include the experiential knowledge about where and when certain varieties of plants grow, and what actions to take to best nurture them. The development project currently grants validity to this level of abstraction by recasting indigenous knowledge in scientific terms $^{92}$. The 'secondary level' refers to the concepts that explain these experienced pieces of knowledge and unite them in a knowledge system. This is also the framework for understanding new experiences and for creating new meaning ${ }^{93}$.

\section{Brodt suggests that}

"the fact that particular knowledge elements used locally have different histories or points of origin is not necessarily a hindrance in creating a viable local composite knowledge system" ${ }^{\prime 4}$.

Because cultural meaning is included as part of the technology, societies are not only influenced by a new technology but also actively recreate the technology itself. It is this recreation of technology which dispels the myth of a single, linear technological development. Similarly, the adoption of new technologies alters cultures in unpredictable ways. For instance, interactions with new cultural ideas may alter practices and perceptions at the primary level, while leaving the secondary level unaltered and vice versa ${ }^{95}$. Furthermore, because it is not necessary (or possible) for every member of a society to be familiar with all aspects of a culture, the effects of changes at the level of individual knowledge systems may differ. In particular, this may occur in societies that have 'gatekeepers' to the secondary level

\footnotetext{
${ }^{91}$ Brodt, "Interactions of Formal and Informal Knowledge Systems in Village-Based Tree Management in Central India." p. 356, S Brodt, "Learning About Tree Management in Rural Central India: A Local-Global Continuum," Human organization 61, no. 1 (2002).

92 Francesco Mauro and D. Hardison Preston, "Traditional Knowledge of Indigenous and Local Communities: International Debate and Policy Initiatives," Ecological Applications 10, no. 5 (2000). p. 1263

93 Brodt, "Interactions of Formal and Informal Knowledge Systems in Village-Based Tree Management in Central India."

94 Ibid. p. 360

95 Ibid.
} 
concepts - e.g. religious/spiritual or political leaders - or have practices that are organised into distinct professions where knowledge pools at the primary level.

A weak understanding of social constructivism might recognise that only the secondary level is culturally mutable, whereas information at the primary level is objective. However, this argument can be refuted when recognising that these levels mutually reconstitute one another. Explanations of what makes particular crop varieties grow well, whether these refer to micronutrients in the soil or to cosmology, depend at a practical level upon how the crop is used. For instance, new HYV of rice may outperform local varieties in the production of edible kernels, but at the expense of equally useful of stems and leaves, which are used for a variety of purposes from animal fodder to thatching, bedding, and importantly to improve soil conditioning and reduce evaporation of moisture from the soil $^{96}$. These practical considerations undoubtedly help construct more abstract concepts, which in turn feed back into an understanding of practical considerations. This process ensures that the production and re-production of culture are continuous processes, creating open and dynamic systems rather than ones that are closed and static.

Thus, synthesis imparts to recipient cultures a role in their own transformation and an agency often neglected by development discourse. In itself synthesis neither supports nor confirms the claim that non-Western cultures are eroded by the adoption of Western technology. This claim is often based upon a perceived 'authentic' culture which must be preserved, however, and is subsequently incompatible with the notion of synthesis developed here. Furthermore, synthesis requires that Western and nonWestern cultures are not mutually exclusive or qualitatively different. Overall, it suggests that culture is dynamic, regardless of whether one is referring to so-called 'modern' or 'traditional' societies.

\subsection{The incommensurability of cultural knowledge}

The concept of synthesis is challenged by the assertion, made by philosophers of technology and science, cultural imperialists, and at least

${ }^{96}$ Shiva, Monocultures of the Mind. 
implicitly by many development theorists, that different forms of cultural knowledge are incommensurable. That is, they are qualitatively different or mutually exclusive such that they cannot be combined. Modern technology, according to Heidegger, is qualitatively different from pre-modern technology, which simply reveals nature. In contrast, modern technology transforms, stores and "challenges" nature forth to reveal itself ${ }^{97}$. In doing so, humankind does not create, in the sense that García Bacca suggested, as a God brining new objects into being, but rather transforms 'objects' with actual Being into resources, stocks and standing reserves. In other words, modern technology transforms natural objects into artefacts defined by their function in relation to humanity. Objects lose their "thingness" and become instead "objects with no inherent value apart from human use" 98 .

Mumford similarly distinguished between two types of technologies that broadly coincide with the Western/non-Western divide. He argued that humanity was at a turning point in their relation to technology, passing from an age where technological innovations focused upon the "mastery over the forces of nature" to a "radically different condition" - one in which humankind has "not only conquered nature,...but detached himself as far as possible from the organic habitat" $"$.

These new technologies, which are representative of Western innovations, Mumford termed monotechnologies (or, alternatively, megatechnics). Monotechnologies were directed towards the pursuit of power, both economic and military. With this power technology would create a "uniform, all-enveloping, super-planetary structure" which is authoritarian and monolithic ${ }^{100}$. In contrast, he considered 'pre-modern', non-Western technology to be "life-oriented, not work-centred or power-centred"101. These he termed 'polytechnologies' in reference to the myriad of human needs they address and their democratic nature. Mumford's analysis suggests that people are consumed by the modern technological system and, once part of it, are constrained in other aspects of their lives.

\footnotetext{
97 Smith, "Heidegger, Technology and Postmodernity.", Rivers, "An Introduction to the Metaphysics of Technology."

98 Mitcham, Thinking through Technology: The Path between Engineering and Philosophy. p. 52

99 Mumford, The Myth of the Machine: Technics and Human Development. p. 3

100 Ibid. p. 3

101 Mumford (1967) quoted in Mitcham, Thinking through Technology: The Path between Engineering and Philosophy. p. 43
} 
In applying the concept of synthesis to these arguments, it would appear that Heidegger and Mumford both fail to look beyond the uses and meanings of technology constructed by Western society. Both suggest that modern technologies represent a new chapter in humanities relationship to social and natural world, either through our capacity to recast nature as functional objects or to accumulate power and dominate. These arguments are rooted in the historically unique Western perception of a mechanical natural world, which originated with Descartes during the scientific revolution and is captured in the idea of God as a watchmaker. They do not make allowances for the different meanings that other cultures may construct for these technologies, meanings that do not entail a purely functional perception of nature and human activity. Treating the interaction of cultures (not merely between Western and non-Western, but also amongst non-Western cultures) as a synthesis rather than as mimicry or displacement acknowledges the agency of the subaltern not only in responding to these interactions, but also in producing their own knowledge and discourse. Thus, the dominance and influence of the West may be recognised without granting Western culture a deterministic influence in its dealings with other cultures ${ }^{102}$.

Western and non-Western technologies have also been differentiated according to their 'inherent' effects in the development discourse. In recent times the qualitative differences of indigenous knowledge relative to their western counterparts, particularly in regard to sustainable development, has been a focal issue amongst development agencies. Indigenous knowledge has been positioned as a counterpoint to the negative outcomes of modernity, such as social dissolution and environmental degradation ${ }^{103}$. This delineation is often made by referring to Western technology as driven almost entirely by individually motivated rational self-interest, while nonWestern technology is proclaimed to be rooted in tradition and inherited

102 F Cooper, "Conflict and Connection: Rethinking Colonial African History," The American Historical Review 99, no. 5 (1994).

103 Nandy, Traditions, Tyranny, and Utopias: Essays in the Politics of Awareness, JN Pieterse, "After Post-Development," Third World Quarterly 21, no. 2 (2000), Rist, The History of Development: From Western Origins to Global Faith, RJ Smith, "Sustainability and the Rationalisation of the Environment," Environmental Politics 5, no. 1 (1996). 
practices which benefit the community rather than the individual ${ }^{104}$. This characterisation implies that tradition is a slow moving and constraining force in opposition to rational choice and the individual's freedom to make decisions based on calculations of opportunity costs and potential gains.

This dehumanising representation of tradition, which strips the individual of agency and independent thought, is critiqued by Tim Ingold. He argues that the proposed distinction between traditions, which are believed to limit the choices of individuals to such a degree that they resemble automatons carrying out predetermined tasks, and rational, calculating scientific individuals who freely pursue an optimal strategy is one that allows only the latter to be truly human ${ }^{105}$. In opposition to such a view of tradition he suggests a method of cultural learning for hunter gatherer societies which is not merely mimicry, but enskillment through apprenticeship and practical experience ${ }^{106}$. This more amicable understanding of traditional practices returns agency to the individual and allows tradition to be a flexible set of knowledge and practices that is not necessarily averse to change.

In an example of this process, Pacey recounts the 'fit' of the snowmobile into Lapp and Inuit society ${ }^{107}$. The snowmobile became popular in North America during the 1960s. Its design and marketing corresponded to the needs and desires of its largest user group: the recreational user. Snowmobiles were subsequently built for short trips in areas where there is ample access to fuel or service stations. However, they were also widely adopted by Inuits who used them for long expeditions in the Arctic. While travels using the traditional means of transport, the dog-team and sledge, meant that 'fuel' requirements could be met by hunting along the way, a large supply of fuel needed to be brought on any trip with the snowmobile as there was generally no possibility of accessing more once off the beaten track. In addition, the remoteness of their travels required of the Inuit user that he/she be able to make any urgent repairs to the vehicle him/herself, and only using basic tools. With a tradition of problem solving and 'home

\footnotetext{
104 Tim Ingold, "Chapter 2: The Optimal Forager and Economic Man," in Nature and Society: Anthropological Perspectives, ed. P Descola and G Pálsson (London \& New York: Routledge, 1996).

105 Ibid.

106 Ibid. p. 40

107 A Pacey, The Culture of Technology (The MIT Press, 1983).
} 
repairs' the Inuit snow mobiles have, therefore, been substantially modified to suit their local needs and wishes ${ }^{108}$. Local cultural mores were, therefore, instrumental in optimising a new technology to suit the local need, while the local traditions were flexible enough to allow the adoption of motorised transport. Consequently, synthesis implies that western and non-western cultures do not exist in mutually exclusive domains between which there can be no dialogue. Moreover, this example clearly demonstrates that utility is not an inherent quality of the technology itself and cannot be assumed to necessarily become established in another culture unless their norms and values are also shared.

\subsection{Technological imperialism and power}

If it were, in fact, the case that the adoption of Western technology necessitated such a 'package deal', then technology translation would not result in cultural synthesis. Rather it would represent a form cultural imperialism that is dubbed technological imperialism. Cultural imperialism refers to "a process of cultural domination in the absence of direct political control" ${ }^{109}$. In this case, technological imperialism invokes the preclusion of non-Western societies to determine their own technological future because of the cultural domination of Western scientific technology. While technological imperialism does not necessarily consider Western and nonWestern technologies as incommensurable, it is often presented as such. For instance, Shiva writes of the considerable effect that the transfer of modern biotechnology with the supporting intellectual property rights regime has had in breeding a 'monoculture of the mind'110. She argues that the association of Western agricultural science and technology with political and economic power ensure that local science and technology are supplanted with often devastating results for local communities. Lamenting the loss of local, sustainable, forestry and agricultural practices used by communities throughout India during and after the Green Revolution, Shiva

\footnotetext{
108 Ibid.

109 R Dunch, "Beyond Cultural Imperialism: Cultural Theory, Christian Missions, and Global Modernity," History and Theory 41, no. 3 (2002). p. 308

${ }^{110}$ Shiva, Monocultures of the Mind.
} 
perceives the two paradigms as "cognitively and ecologically incommensurate"111.

Technological imperialism is not necessarily a purposeful act or the result of a cooption of powerful groups or government agencies, however. It may instead be the sum of influences, large and small, of one culture upon another measured by the impact the one has upon the other ${ }^{112}$. This is not incompatible with the concept of synthesis. Instead it highlights that it is impossible to consider the synthesis of cultures as being unaffected by the existence of power relations. The dominance of the development discourse with its pejorative perception of non-Western societies as pre-modern and underdeveloped, the prior colonial relationship between many non-Western cultures and the West, and the capital and influence of many Western companies, are all examples of how power has been used to influence the adoption of new technologies.

Despite the coercive transfer (in the true sense) of Western populations and their socio-cultural traits during colonial times, however, hybrid technologies still emerged during this era. For instance, Derbyshire details how the construction of India's railways by British and locally educated engineers during British rule led to a combination of British technology and Indian techniques that altered civil engineering practices in both countries $^{113}$. Nonetheless, even in the post-colonial period, when direct political control was lifted, the charge of Western imperialism has remained. This was originally due to the continued grasp the local elites educated in the Western tradition held on the fledgling states, but later also due to the pervasive influence of Western dominated markets. According to those, such as Shiva and Chambers, who perceive technological imperialism to be taking place, Western technology is spread by the structures of power that still define the relationship of the West with the rest of the world ${ }^{114}$. These power relationships include the influence of a number of international

\footnotetext{
111 Ibid. p. 20

112 Dunch, "Beyond Cultural Imperialism: Cultural Theory, Christian Missions, and Global Modernity."

${ }^{113} \mathrm{M}$ Adas, "A Field Matures: Technology, Science, and Western Colonialism," Technology and Culture 38, no. 2 (1997). Also see RM MacLeod and D Kumar, Technology and the Raj: Western Technology and Technical Transfers to India, 1700-1947 (Sage Publications Pvt. Ltd, 1995).

${ }_{114}$ R Chambers, Rural Development: Putting the Last First (Longman London, 1999), Shiva, Monocultures of the Mind.
} 
organisations, international markets and trade rules, and the development project itself. This suggests that the adoption of available technology is not as voluntary or without considerable pressure from mediators.

House, Hanges, Javidan, Dorfman, and Gupta have considered how national leaders act as mediators of technological innovations by setting national goals for technological development and thus signalling to the population what technologies are preferred in the national strategy or for the future 'direction' of the nation ${ }^{115}$. Similarly, diffusion studies often highlight the role of various mediators in spreading technological innovations. Mediators are people with the ability to make new technologies culturally relevant and also to influence the construction of meaning for various technologies. The act of mediating between the producers or diffusers and the users of technology is a powerful position, particularly as it often entails providing information about what the technology is, how it works and how it is relevant for a particular target user group.

This may be done through actions, e.g. a high status member of society adopting a particular technology, or through words, e.g. the work of extension officers, employed by central and state governments and agricultural universities, who educate farmers about available technologies. Promotion by seed companies and their distributors also mediate new technologies ${ }^{116}$. Hence, the mediator has a role (which may be more or less influential) in translating new technologies and constructing the space of relevance within a particular cultural context. There are also mediators who, as is the case for many academics and NGO or development agency staff, interpret the needs and wishes of the target users and speak for these groups on the international stage. Shiva is particularly critical of the increasing communicative distance between producers and consumers of technology. Her work with farmers struggling with debt burdens following investment in new Western technologies has shown that considerable hardship and despair have frequently been the result ${ }^{117}$.

115 Steers, Meyer, and Sanchez-Runde, "National Culture and the Adoption of New Technologies." See also RJ House et al., Culture, Leadership, and Organizations: The Globe Study of 62 Societies (Sage Pubns, 2004).

$116 \mathrm{~N}$ Lalitha, "Diffusion of Agricultural Biotechnology and Intellectual Property Rights: Emerging Issues in India," Ecological Economics 49, no. 2 (2004).

${ }_{11}$ V Shiva, "The Future of Food: Countering Globalisation and Recolonisation of Indian Agriculture," Futures 36, no. 6-7 (2004). 
It may be the case that Western technologies, whose patent laws and production requirements make their designs invisible and adaptation by end-users impossible, are adopted as a 'package'. Thus, power relationships cannot readily be discounted in the process of translation. However, the method of transfer and the basis for the adoption of technology also affects the meaning that a technology gains. Accordingly, the forced or coerced adoption of technologies may produce in their new cultural context a meaning strongly shaped by resistance, protest and oppression. Bebbington describes that for many indigenous cultures in Ecuador, Western technology has been so blighted by associations with past power relationships that it is now rejected wholesale ${ }^{118}$. Paradoxically, other indigenous peoples have responded to similar historical relationships with the West by embracing new Western innovations as evidence of their improved social and economic status.

The responses of different cultures and knowledge systems to these power relations, therefore, are varied and unpredictable. Unequal power relations do not preclude synthesis, although they may considerably alter the way in which cultures change and what meanings are attributed to new technologies. This shows that even where Western technologies are adopted as a package, including Western social and economic practices (which I would argue is a condition imposed by the donors rather than a necessary condition of technology adoption), they do not replace the local culture. Therefore, I do not consider Western and non-Western technologies to be mutually exclusive entities which thereby necessarily preclude the possibility of cultural synthesis.

\subsection{Summary}

This chapter introduced the concept of synthesis as the dominant mode of cultural and technological hybridisation following the translation of technology. Technology translation requires that the donor and recipient cultures interact. Synthesis implies that this interaction produces emergent social and technological outcomes. This emergent property means that these outcomes are not predictable through prior knowledge of the

118 Bebbington, "Indigenous Agricultural Knowledge Systems, Human Interests, and Critical Analysis: Reflections on Farmer Organization in Ecuador." 
characteristics of the donor and recipient cultures. Furthermore, this property leads to cultural synthesis being a non-deterministic and openended process.

Synthesis also requires that donor and recipient cultures are not incommensurable. This accusation has been levelled at Western and nonWestern cultures by several philosophers of technology as well as supporters and critics of the development project. I argue that this perceived incommensurability has arisen mistakenly because the diverse cultural meanings of technology are seldom examined in practice and because non-Western cultures are often falsely stereotyped as existing in a dichotomy with West. Finally, technological determinism and power relationships were explored as possible impediments to synthesis. It was concluded that power does have an effect upon whether or not technologies are adopted, but that this does not amount to technological determinism because recipient societies partly construct the meaning of technology based upon the mode of adoption.

Hence, while this section removes some of the major theoretical impediments to synthesis taking place; it does not in itself provide evidence of synthesis. The following chapter examines the empirical evidence for technology translation and synthesis with case studies from Indian agriculture. 


\section{EVIDENCE OF TECHNOLOGY TRANSLATION AND SYNTHESIS}

This chapter examines the empirical evidence for technology transfer. The evidence presented has been derived from the well documented history of technological adoption within Indian agriculture. Despite the wealth of literature on the subject, however, how the donor and recipient cultures interact in process of technology translation has so far remained unexplored.

I begin with a short explanation of what I consider to be evidence for technology translation and synthesis. Evidence for synthesis is contrasted with that for coexistence or additive hybridisation. Secondly, an outline is provided of the three phases of technology introduction into India. This provides the background upon which the mode of technology translation is described. Finally, two case studies examine how hybridisation has taken place following the introduction of technology within Indian agriculture. The first study involves the incorporation of Green Revolution technologies into the Indian system of humoral agronomy. The second study examines the recent policy response by Indian politicians to the introduction of genetically modified (GM) food crop varieties and the associated Intellectual Property Rights (IPR) regime to Indian agriculture. In both studies the interaction between the Indian and Western cultures that followed the introduction of a new technology gave rise to unique and emergent outcomes that redefined the utility and perception of the technology.

\subsection{What constitutes evidence for technology translation?}

The definition of technology adopted by the development discourse is as an artefact with a universally applicable - that is, culturally neutral - utility and set of meanings. Under this definition, technology transfer describes the process by which technologies and knowledge systems of the recipient society are replaced by those of the more advanced donor society. Hence, the expectation is that the recipient society can be leapfrogged to the same level of technological development as the donor society, thereby eradicating the need to progress through any intermediate stages. In contrast, technology translation is defined to occur when the meaning ascribed to the technology incorporates ideas from both the donor and recipient knowledge 
systems, producing a hybridised set of meanings. When hybridisation occurs through synthesis, then these meanings are emergent - they cannot be predicted based on knowledge of their cultural forbearers. Technology transfer, therefore, requires that the two knowledge systems coexist but do not interact - no dialogue occurs between them - such that the origins of the technology would remain evident through the lack of admixture. In contrast, evidence for hybridisation via synthesis requires that deconstruction into easily discernible donor and recipient components is not possible.

Between these two conceptualisations of technology adoption lies additive hybridisation. This mode comprises new technologies that are derived from the additive summation of two cultures. Like synthesis, additive hybridisation involves the cultural construction of meaning that takes place during technology translation. Additive hybridisation is nonemergent, however, since its final character can be predicted solely on knowing its cultural antecedents. Consequently, it remains possible to clearly distinguish the donor and recipient elements of the hybrid technology because nothing new is added by their interaction. Bearing this in mind, in the next section I examine the empirical evidence for technology translation and hybridisation in Indian agriculture.

\subsection{Technology translation in Indian agriculture}

Attempts to modernize the Indian economy and society by Western colonialists, development experts and Indian nationalists have occurred in several historical junctures with varying effects upon Indian culture. In what follows I examine three particular stages for evidence of technology translation: 1) the period of British colonialism, 2) the Green Revolution following Indian independence and 3) the current Gene Revolution.

\subsubsection{British colonialism}

The Industrial Revolution brought about tremendous and rapid technological change to Britain and Europe in the $18^{\text {th }}$ century ${ }^{119}$. These changes resulted in an increased efficiency of labour in the production process - i.e. the ability

119 Saptal Sangwan, "Level of Agricultural Technology in India (1757-1857)," Asian Agri-History 11, no. 1 (2007). p. 20 
to produce more per labour hour input - and this came to signal progress in productive technologies. Consequently, agents of the British East India Company considered the technologies they encountered in $18^{\text {th }}$ century India to be primitive by comparison ${ }^{120}$. For instance, while Indian tools such as the weeding-plough and common hoe had British equivalents in utility and design, the Indian versions tended to be constructed of bamboo or hardwood, whilst the British versions were forged in iron. Agents of the Company considered Indian tools to be highly inefficient. Iron tools could reach farther into the soil and required less maintenance than their Indian counterparts, thus requiring less labour input overall ${ }^{121}$.

Introduced iron tools imported by the British East India Company were, however, to a large extent rejected by the Indian farmers. While iron was certainly not unknown in Indian agriculture, tools made from iron were too costly for the majority of Indian farmers, and less effective wooden tools were often preferred because they could be produced and maintained locally and at little or no cost except time ${ }^{122}$. A particular division of labour had also sprung up to support the use of these tools, including local builders and stone masons as well as professional diggers, which did not exist, or existed in only a limited form, for iron tools. In comparison, British tools required a local or even onsite foundry for repairs, implying that substantial changes to the division of labour and to local infrastructure would be required in order for British machinery to be widely adopted.

Ignorant of these social dynamics, the British were baffled by the refusal of local farmers to adopt the seemingly more efficient Western technologies. In the Western experience of technological change, iron was a more advanced material whereas wood symbolised past inefficiencies ${ }^{123}$. This and other similar experiences promoted the perception amongst the British that indigenous technologies were static, mired in tradition, and inefficient. In contrast, the theory of technology translation would suggest that the local materials simply did not have the pejorative meaning in India

120 In comparison with other non-Western cultures they were acknowledged to be fairly advanced. The criteria for such an assertion being that the design of Indian agricultural tools resembled that of the tools used by British farmers.

121 Sangwan, "Level of Agricultural Technology in India (1757-1857)."

122 Ibid.

123 Ibid, Mitcham, Thinking through Technology: The Path between Engineering and Philosophy, RLB Hooke, "On the History of Humans as Geomorphic Agents," Geology 28, no. 9 (2000). 
that they held for the British. Therefore, they were not predisposed to consider introduced iron technology as more advanced, and the decision to adopt or forgo these technologies was based upon pre-existing local socioeconomic factors. The selective adoption of several British technologies in India from the end of the 1700s and particularly after Company rule was replaced by Crown rule in 1858 dispels the myth that Indian culture and technology were static and limited by tradition during this period ${ }^{124}$. These technologies included the adoption of water-power, increased use of irrigation systems and iron parts incorporated into the native plough.

Additionally, social changes were instituted in India during the period of direct British rule as part of their 'civilising mission' which influenced the adoption of British technologies. For instance, trade links were established with Britain which benefitted certain Indian producers. However, this necessitated the creation of strict private property rights, international free trade, and the creation of infrastructure - in particular road and rail networks to rapidly move products to ports ${ }^{125}$. Furthermore, the British administration sought to create

"a class who may be interpreters between us and the millions whom we govern, a class of persons, Indian in blood and color but are English in taste, in opinions, in morals, and in intellect"126.

These individuals were to be university educated and act as mediators between the British administration and the local population. Their task was to increase the rate of adoption of Western technologies within the broader Indian society.

Within the Indian universities, this educated elite also carried out research into increasing the productivity of the crops in which Britain had a particular interest. These included cotton, tea, rubber and jute which were sold to the British market rather than used for local consumption. As Anderson and Morrison point out, research into these crops did not tend to increase the average Indian farmer's productivity, as most local small

${ }^{124}$ Sangwan, "Level of Agricultural Technology in India (1757-1857)." p. 22 125 Gupta, Postcolonial Developments: Agriculture in the Making of Modern India.

126 Macauley Minute of Education 1835 quoted in P Rama Rao, "India: Science and Technology from Ancient Time to Today," Technology in Society 19, no. 3-4 (1997). p. 417 
holders produced food rather than cash crops $^{127}$. Cash crops were typically grown on larger plantations and the direct effects of scientific research into these crops were, therefore, confined to only a small portion of the farming community.

While one might infer from this that local and Western scientific technologies and culture simply coexisted with their Indian counterparts, their wider effects upon Indian society indicate that this was not the case. For instance, access to British markets increased the wealth and political influence of those with substantial landholdings, but not the landless or the smallholder. This enabled such landowners to dictate employment conditions for agricultural labourers who were often landless peasants. Furthermore, cash crop production on large plantations enabled the introduction of more expensive mechanical technologies that also altered the labour relationship between the farm owner and the labourer. Consequently, these technologies came to be associated with wealth as well as inequality in rural India.

\subsubsection{The Green Revolution}

Following independence, the civilising mission of colonialism was superseded by the strikingly similar goals of development. These goals were to increase India's involvement in international markets, to increase the role of the industrial sector in the Indian economy, and to bring India's social and political systems in line with the Western ideal. The technological focus of early Indian nationalist governments was upon strengthening the industrial sector. However, this could not be achieved without simultaneously increasing the domestic food supply and reducing the cost of urbanisation. This was first attempted through a combination of land reform and community development programmes coupled with the import of U.S. food aid under the U.S. Public Law (PL) 480. In retrospect, these policies have been considered a resounding failure. Within as little as 10 years, India went from being a net exporter to a net importer of grain ${ }^{128}$. By the 1960 s, when U.S. food aid became conditional upon agricultural modernisation and India

$\overline{127}$ RS Anderson and BM Morrison, "Science, Politics, and the Agricultural Revolution in Asia" (paper presented at the AAAS Selected Symposium, San Francisco, 1982). p. 5

${ }^{28}$ Gupta, Postcolonial Developments: Agriculture in the Making of Modern India. 
had amounted large international debts, technical assistance initiated the second, post-colonial, stage of technology imports.

In the U.S., heavy investment in agrochemical research for the purposes of achieving national self-sufficiency in food production had been emphasised in the period directly following the Second World War. This resulted in an agricultural sector based upon industrial style production, which was reliant upon biochemical and petrochemical inputs, and vastly increased labour productivity. Simultaneous scientific discoveries relating to the nature of heredity opened up new possibilities in the breeding of life forms with increased agricultural yields. Thus, high yielding varieties (HYV) of corn and wheat supported by chemical fertilisers, pesticides and herbicides dramatically changed the face of U.S. farming and increased the yields of several U.S. export crops. Agro- and petrochemical inputs, such as fertilizers, pesticides, herbicides and HYV seeds were also exported commercially, particularly to Europe. While, this produced considerable earnings for their producers and investors, the interest in transferring these technologies were not purely economic. For instance, the U.S. was particularly interested in containing the spread of communism in Asia by stabilising what was seen as a Third World countryside primed for revolution. U.S. officials believed that both the economic and political goals could be achieved by alleviating hunger and improving living conditions in developing countries - essentially by creating peasant middle classes in a number of Asian, Latin American and African states.

The adoption of these technologies in the developing world was given the sobriquet the 'Green Revolution' $(G R)^{129}$. The GR began in Mexico in 1943 and by the 1960s had spread to several Asian countries including India ${ }^{130}$. In India the mediators for the diffusion of GR technologies were the national government, which adopted policies favourable to industrial agriculture, and a growing number of research and development institutes that supported the move as a means to address hunger. Western governments, corporations and foundations were also conspicuous in this process through their close association with many of the research institutes

\footnotetext{
129 Gupta notes with interest that this term was never used to denote the same changes to agricultural technology in the U.S. or, to a lesser extent, in Europe.

${ }^{130}$ R Hindmarsh, "Genetic Modification and the Doubly Green Revolution," Society 40 , no. 6 (2003).
} 
based both in the West and in Asia. In particular, the Rockefeller Foundation set up research institutions in Asia, and also helped create the Consultative Group on International Agricultural Research (CGIAR) to oversee and coordinate the activities of international agricultural research centres ${ }^{131}$.

The GR, therefore, was a revolution from the top down. The orchestrators of the GR understood the necessity of making its technologies relevant to the Indian farmer. It was, for instance, not until HYV of widely grown crops, specifically rice ${ }^{132}$, became available that Indian farmers adopted GR technologies. Prior to the adoption of HYV rice, the available GR crops had no counterpart in Indian agriculture (although Indian farmers were indirectly influenced by GR agriculture in the U.S. and Mexico ${ }^{133}$. Furthermore, there was also a push to create a favourable climate for the GR technologies in the recipient cultures. Extension agents and agro-service centres that were financed by governments, universities and corporations, and the use of GR technologies on state-owned farms, were employed to educate local farmers about the available innovations and advertise the technology. Accordingly, during and following the Green Revolution there was an intense pressure upon Indian farmers to adopt new, scientific modes of farming.

The adoption of these technologies by Indian farmers yielded mixed results. GR technologies certainly did not eliminate hunger on the subcontinent, but they did increase agricultural productivity and labour efficiency. Where sufficient land was available, farmers were able to put more into production because the labour requirements per hectare were reduced. With the use of chemical fertilisers, crops also grew more rapidly, allowing an additional sowing per season to be achieved in some areas. These effects were limited to the farmers who could meet the payments for both the seeds and the inputs, however, and those who had access to well irrigated land. Farmers with smallholdings, tenant farmers and farm labourers did not experience similar increases in production because of to their inability to access these technologies, as had also been the case for small farms in the U.S.

\footnotetext{
${ }^{131}$ Ibid.

132 Produced by the Rockefeller and Ford Foundation funded, Philippines based International Rice Research Institute (IRRI).

${ }^{133}$ Gupta, Postcolonial Developments: Agriculture in the Making of Modern India.
} 
In contrast to the U.S., socioeconomic divisions in India were intertwined with the Hindu caste system, whereby particular castes benefitted disproportionately. Also Christians and Muslims, who had been incorporated into the caste system in rural areas, were affected by the restrictions that a low caste placed upon accessing land, water or chemical inputs despite a national ban on caste-based discrimination ${ }^{134}$. Farmers' decisions about whether and to what extent to adopt GR technologies were, therefore, intertwined with local politics and individual household economics $^{135}$. GR technologies have therefore been attributed a range of meanings relating to wealth and status, religion, debt and opportunity that they are not imbued with in the West.

\subsubsection{The Gene Revolution}

As the productivity gains of the GR diminished in the 1980's, the 'Second Green Revolution', or the 'Gene Revolution' as it is also known, began to spread its influence ${ }^{136}$. The central thrust of the Gene Revolution entailed the use of genetically engineered organisms in the production of food crops. The term 'genetic engineering' is used here to refer to the "introduction or elimination of specific genes through modern molecular biology techniques"137. This technology had its basis in discoveries made in the late 1960s and 1970s that allowed DNA chains to be broken at specific locations, isolated and joined together to produce a recombined DNA strain within a cell $^{138}$. Once again, the Rockefeller Foundation has played a pivotal role in financing research into the engineering of life forms for agriculture, thereby helping to establish this field of biotechnology.

The Gene Revolution remains an area of contention in much of the developed and developing world. Supporters of the Gene Revolution believe that the spread of such technology will reduce the need for the industrial inputs such as pesticides, herbicides and fertilisers that made the GR

134 MN Srinivas, "Caste in Modern India," The Journal of Asian Studies 16, no. 4 (1957), SA Wolpert, A New History of India (Oxford University Press, USA, 2004).

135 Gupta, Postcolonial Developments: Agriculture in the Making of Modern India.

136 Govindan Parayil, "Mapping Technological Trajectories of the Green Revolution and the Gene Revolution from Modernization to Globalization," Research Policy 32, no. 6 (2003).

${ }_{137}$ A Zaid et al., Glossary of Biotechnology and Genetic Engineering, ed. FAO, Fao Research and Technology Papers - 7 (Rome: FAO, 1999 ). p. 106

${ }^{138}$ Hindmarsh, "Genetic Modification and the Doubly Green Revolution." 
economically and environmentally unviable for much of the developing world, while relying upon the engineered traits of the crops themselves to further increase yields ${ }^{139}$. On the other hand, its detractors see it as an updated form of bio-imperialism in the same fashion of the GR. Fears exist that the rich biological diversity and farmers' ability to breed and save seeds would be lost to Western companies, leaving Indian farmers indebted and India's food security dependent upon Western seed producers. This process has been called biocolonialism ${ }^{140}$.

The diffusion of GM technologies has expanded upon the distribution networks laid down during the first Green Revolution. This includes the network of research institutes, the creation of further international institutions, and an international legal framework for the protection of intellectual property rights (IPR) for genetically engineered organisms ${ }^{141}$. This legal framework has been particularly important because the production and distribution of GM technologies is undertaken by private companies for whom IPRs provide economic incentives. Just as in the case of the Green Revolution, creators and disseminators of genetically modified crops have recognised the need to make pre-emptive investments to cultivate a regulatory and cultural environment positively disposed to the new GM technologies. Thus, it is evident that the creators and distributors of these technologies recognise that "factors linked to cultural considerations, such as education and the need to foster modern cultural values" are a prerequisite for the successful introduction of these new innovations ${ }^{142}$. Initiatives to ensure that GM meets with a positive reception have included:

“a media program involving training promising young journalists to present pro-biotechnology perspectives...; a public education program aimed at public acceptance of GM...; the preparation of information resources and materials for elementary and high school students;

\footnotetext{
${ }^{139}$ Cohen and Paarlberg, "Unlocking Crop Biotechnology in Developing Countries--a Report from the Field."

${ }^{140}$ Escobar, "The Making and Unmaking of the Third World through Development.", A Escobar, "Whose Knowledge, Whose Nature? Biodiversity, Conservation, and the Political Ecology of Social Movements," Journal of Political Ecology 5, no. 1 (1998).

${ }^{141}$ Hindmarsh, "Genetic Modification and the Doubly Green Revolution."

142 Escobar, "The Making and Unmaking of the Third World through Development." p. 86
} 
encouragement of bioindustry-academia collaborations; and the setting up of...laboratories"143.

Within some sections of the Indian science community, the technologies for carrying out research into, and production of, GM crop varieties have been adopted creating a thriving biotechnology industry. In 2004 there were an estimated 50 public research institutions, and 45 private and foreign companies engaged in genetic engineering research for agriculture in India ${ }^{144}$. With the establishment of local agricultural research institutes, biotechnology departments in universities, and biotechnology companies throughout India, GM technologies are now often produced locally. Furthermore, research has become increasingly focussed upon domestically popular crops such as rice, eggplant, capsicum, cabbage and chickpeas (to name only a few) rather than cash crops for the international market $^{145}$.

The adoption of internationally IPR protected GM technologies, however, has necessitated the creation of new institutions within India to manage their legal and food and environmental safety implications. In India alone a Recombinant DNA Advisory Committee, a Review Committee of Genetic Manipulation, an Institutional Biosafety Committee, a Genetic Engineering Approval Committee (GEAC), a State Biotechnology Coordination Committee, and a District Level Committee, not to mention the Department for Biotechnology have been instituted within the national government ${ }^{146}$. The need to create, fund and to acquire the expertise to assess and monitor GM crop use and safety are seen as obstacles to the diffusion of these technologies within developing countries including India ${ }^{147}$.

The diffusion of GM crops in India has been delayed by the regulatory and biosafety regulations administered by the Ministry of Environment and Forest's Genetic Engineering Approval Committee. Cohen described this as

\footnotetext{
143 Hindmarsh, "Genetic Modification and the Doubly Green Revolution." p. 17

144 Lalitha, "Diffusion of Agricultural Biotechnology and Intellectual Property Rights: Emerging Issues in India." p. 191

145 FAO, "Biotechnologies in Developing Countries: India," FAO, http://www.fao.org/biotech/inventory_admin/dep/default.asp. Accessed: 20.02.2010 ${ }^{146}$ Ministry of Environment \& Forests, "Regulatory Reforms in Biotechnology Article 4," Department of Biotechnology, Ministry of Science and Technology, http://dbtindia.nic.in/uniquepage.asp?id_pk=112. Accessed: 20.02.2010

${ }^{147}$ Lalitha, "Diffusion of Agricultural Biotechnology and Intellectual Property Rights: Emerging Issues in India."
} 
government officials "denying to Indian farmers this technology so well suited to their pest control needs and so widely in use elsewhere"148. In reality, however, there has been considerable resistance to GM technology based partly on the same environmental and health concerns expressed by many Western scientists and lay persons, and partly on India's particular social and cultural experiences. In fact, recent public resistance to the GEAC approved GM Bt Brinjal (a genetically engineered eggplant containing genes from the bacterium, Bacillus thuringiensis) forced the Indian Minister for the Environment to place a moratorium upon its release for public cultivation ${ }^{149}$.

It is too early to draw firm conclusions about the adoption of GM crop varieties at the grassroots level. However, a tentative observation offered by Gupta is that such adoption has been influenced by the relationship between Indian farmers and the large and complex bureaucracies of the national and state administrations. For example, farmers often choose not to get purchase orders (equivalent to loans) from government banks. This is not because the seeds aren't suitable for use on their farms, but because the repayment schedules offered by these banks are inflexible and there are also frequent delays in receiving the seed. Additionally, the relationship between government officials and seed merchants is often corrupt. Purchase orders require the farmer to buy seeds from specific merchants, who are thereby able to sell old and inferior seeds. This endangers harvests and the farmers' concomitant ability to repay loans. Thus, deciding what seed to sow may depend upon what is available from family members, friends, or from trusted dealers ${ }^{150}$.

This brief examination of the history of technological adoption in India shows that the adoption of new technologies has been selective. Many colonial technologies were rejected, and Green Revolution technologies were adopted only when they became relevant to Indian farmers. The meanings attained by adopted technologies were affected by how the technologies were imported and by local politics, religion and economics.

148 Cohen and Paarlberg, "Unlocking Crop Biotechnology in Developing Countries--a Report from the Field." p. 1567

${ }^{149}$ Anonymous, "India Puts on Hold First Gm Food Crop on Safety Grounds " BBC News online at http://news.bbc.co.uk/2/hi/8506047.stm 09.02.2010 , T.V. Padma, "India Says No - for Now - to First Gm Vegetable," Science and Development Network online at http://www.scidev.net/en/news/india-says-no-for-now-to-first-gmvegetable.htm/ 09.02.2010.

${ }^{150}$ Gupta, Postcolonial Developments: Agriculture in the Making of Modern India. 
Furthermore, adopted technologies did not simply replace existing practices or exist alongside them, but were integrated into the local culture and combined with pre-existing technologies in a way that can be described as hybridisation. The following case studies show that this hybridisation can be best described as a synthesis.

\subsection{The Green Revolution and humoral agronomy}

For the past fifty years, the technologies of the Green Revolution have been widely used across India. However, even in states with the greatest uptake of these technologies such as Uttar Pradesh and Punjab, the technologies of the Green Revolution are mixed with the local concept and practices of 'humoral agronomy'. According to Kurin, humoral agronomy descended from Greco-Arabic sources and has Persian and Indian influences. It refers to the balancing of humors - i.e. hot and cold, dry and moist elements ${ }^{151}$. As explained by Gupta:

"The balance of humors depended on the constitution of a plant, which depended on its intrinsic properties but also on the properties of the soil, fertilizers, water, and wind with which it came into contact. All these inputs conveyed their properties to the plant, which in turn conveyed its properties to humans when ingested as food." ${ }^{152}$

This draws upon Ayurvedic (an Indian system of medicine) classifications of ecology. Kurin explains:

"Hot and cold respectively refer to the expenditure and conservation of energy and wet and dry to the receptivity and resistance of matter."153

Thus, the humoral elements cannot simply be translated into ranges of temperature and moisture levels.

As an example of humoral agronomy in practice, Gupta relates the story of Suresh, a small scale farmer in a village in Uttar Pradesh. Instead of ploughing the soil in his corn fields six or more times before sowing as was

${ }^{151}$ Kurin, "Indigenous Agronomics and Agricultural Development in the Indus Basin." p. 285, Gupta, Postcolonial Developments: Agriculture in the Making of Modern India. p. 157

${ }^{152}$ Gupta, Postcolonial Developments: Agriculture in the Making of Modern India. p. 157

${ }^{153}$ Kurin, "Indigenous Agronomics and Agricultural Development in the Indus Basin." p. 285 
common practice, Suresh ploughed his field only four times. By ploughing fewer times, he prevented the soil from 'drinking' (i.e. trapping and holding) too much water (a cold element) during the monsoon period, which draws heat as steam from the ground and destroys the roots. Thus, ploughing six or more times provided an environment that was too hot and humid for the corn. In contrast ploughing only four times loosened the soil and made it more porous allowing the monsoon rain to drain and, therefore, provided a better balance of humoral elements ${ }^{154}$.

Gupta points out that while the farmers in his study had adopted chemical fertilizers, electric tube wells and high yielding varieties of wheat, the language with which they described the process of agricultural production remained rooted in local concepts rather than Western science ${ }^{155}$. This leads him to ask " $[H]$ ow does one theorize a condition in which disparate epistemologies and practices coexist and interpenetrate with such disarming ease?" He further comments that by using such inputs the Indian farmer did not correspond to the idea of the 'traditional' farmer, but also could not be seen as "essentially the same" as Western farmers ${ }^{156}$.

Gupta's analysis, though showing evidence of hybridisation, does not, in itself, provide evidence of synthesis. Nor does Gupta believe a synthesis of cultures is taking place. Rather he suggests that much of the Western scientific discourse and technology are incommensurable with local discourses of agriculture ${ }^{157}$. Brodt, on the other hand, shows that it is not simply the agricultural practices that have become hybridised, but also the concepts and frameworks which underpin them. For instance, she showed that chemical fertilizers have been fit into the system of humoral agronomy as hot inputs that must be balanced with cold inputs, usually water, in order to ensure optimal plant growth. This is used to explain why the use of chemical fertilisers also necessitates more comprehensive and reliable irrigation techniques, such as tubewells, in order to have a beneficial effect on the growth of the plant. Thus, the introduced biochemical technology has acquired a hybrid meaning that cannot be classified as solely Western or

154 Gupta, Postcolonial Developments: Agriculture in the Making of Modern India. p. 155

155 Ibid.

156 Ibid. p. 156

157 Ibid. p. 156 
Indian ${ }^{158}$. This can be seen to constitute a hybridisation at the conceptual (or secondary level) in Brodt's knowledge hierarchy.

Following the framework developed here, the conceptual recombination of chemical fertilisers and humoral agronomy described by Brodt corresponds to an additive hybridisation of the knowledge systems. The introduced technology is perceived to interact with the local knowledge system, and a new meaning is created which gives it a unique place within the humoral knowledge system. While this particular combination may be unique, it is not unpredictable given knowledge of the two distinct agricultural knowledge systems. The result of the interaction is a hybrid knowledge system wherein it is still possible to distinguish the Western from the non-Western elements. On its own, therefore, this description of the interaction between humoral agronomy and Green Revolution technology does not constitute evidence for synthesis.

Local Indian cultures encompass more than practices and skill sets, however. They include the organisational structures, norms, politics and religious beliefs within societies. Humoral agronomy is associated with Ayurvedic understandings of health and wellbeing, whereby the constitutions or essences of the plants are transferred to the people who grow and consume them ${ }^{159}$. Vasavi describes how farmers in his study connected the physical and ethical character of modern agriculture to those who consumed its products:

"Noting that hybrid seeds are delicate, susceptible to disease and require expensive inputs, villagers, especially those of the older generation, refer.....to the current period as hibred kala (hybrid period) and to themselves as hibred mandi (hybrid people). Unlike the sturdy Javari (organic) seeds they are like the hybrid seeds that they now sow, 'sukshme (delicate), diseased and needing constant attention"160.

The production and consumption of hybrid seeds was related to a vast array of social ills such as

"the attenuation of traditional social relations, the defiance of the younger generation, the urban orientation of the men and youth, the

\footnotetext{
158 Brodt, "Interactions of Formal and Informal Knowledge Systems in Village-Based Tree Management in Central India."

${ }^{159}$ Vasavi, "'Hybrid Times, Hybrid People': Culture and Agriculture in South India." 160 Ibid. p. 295
} 
dependency on the government and on commercial agencies for various agricultural inputs" ${ }^{161}$.

This situation arose not simply because of new economic necessities, but because of the character of the GR crops which Indian's now produced and consumed. Vasavi notes that even genres of music and literature have arisen as a result of the consumption and production of these crops.

Similarly, Gupta notes that farmers in his studies found the chemical fertilisers made the produce taste different to that fertilised using the more traditional cow manure. Consequently, rice grown using chemical fertilisers and hybrid varieties were used for different dishes and on different occasions than organically grown rice and rice of the more traditional desi variety $^{162}$. These new sets of social relations, practices, and causal explanations represent emergent outcomes of the interaction between GR technologies and humoral agronomy. These new features of Indian culture are both unpredictable and impossible to attribute to either these knowledge systems separately or as the sum thereof. This interaction, therefore, represents a synthesis of Western and grassroots Indian culture.

\subsection{The Gene Revolution and India's agricultural IPR policy}

The proposed introduction of GM crops into India as part of the global Gene Revolution is currently under active negotiation. This negotiation takes place not only between Indian farmers and Western development institutions and private seed companies, but also between these farmers and Indian and Chinese biotechnology firms. As a result of government level negotiations, the adoption of GM technology within India has been hindered by the considerable administrative and legal requirements laid down in the international intellectual property rights (IPR) regime. IPRs were extended to include agriculture during the Uruguay round of the World Trade Organisation (WTO) negotiations between 1986 and 1994, and came into effect in $1995^{163}$. The inclusion of agriculture within this agreement was largely due to the increased prevalence of and desire to incentivise private investment in genetic engineering $R \& D$ in the developed countries.

\footnotetext{
161 Ibid. p. $295 \& 296$

162 Gupta, Postcolonial Developments: Agriculture in the Making of Modern India. 163 WTO, "Intellectual Property: Protection and Enforcement," WTO, http://www.wto.org/english/thewto_e/whatis_e/tif_e/agrm7_e.htm.
} 
Meanwhile, developing countries were given a 5 year transitional period in which align their laws and practices with the WTO's TRIPS agreement ${ }^{164}$.

International precedents for domestic IPR regimes are the TRIPS guidelines themselves, which grant IPRs based upon the "novelty, inventive type and industrial applicability of crop varieties" and the Convention for the Protection of New Varieties of Plants (UPOV), which similarly base IPRs on "novelty, distinctiveness, uniformity and stability"165. A further option is to create a unique domestic regime that meets the requirements of the WTO's TRIPS agreement. This was the option chosen by the Indian government and reflected a combination of the two international IPR management strategies and the unique Indian agricultural situation.

In general, public research institutions have not been able to keep abreast with the research carried out by private biotechnology companies. This situation has been exacerbated by the bolstering of incentives for private investment by the TRIPS' patent and plant variety protection regime ${ }^{166}$. Notably, foreign biotechnology companies tended not to focus their research upon common Indian subsistence crops, preferring instead to gain IPRs on more profitable cash crops and the needs of commercial growers. Local biotechnology firms such as the Maharashtra Hybrid Seed Company have been more attentive to the needs of the small scale and subsistence farmers ${ }^{167}$.

The GM crops produced by local companies, however, are frequently 'essentially derived varieties'. This results when local varieties are backcrossed with IPR protected seeds to produce new varieties of GM crops better suited to the local conditions and markets ${ }^{168}$. Hence, there remains a reliance upon foreign biotechnology firms which is worrying for many farmers and public officials. Additionally, there has in recent years been a call for greater investment by private biotechnology firms in 'orphan crops'.

164 Ibid, Lalitha, "Diffusion of Agricultural Biotechnology and Intellectual Property Rights: Emerging Issues in India."

165 Lalitha, "Diffusion of Agricultural Biotechnology and Intellectual Property Rights: Emerging Issues in India." Table 2, p. 194

166 I Matuschke, RR Mishra, and M Qaim, "Adoption and Impact of Hybrid Wheat in India," World Development 35, no. 8 (2007).

167 Ibid.

168 Lalitha, "Diffusion of Agricultural Biotechnology and Intellectual Property Rights: Emerging Issues in India." p. 191 
These comprise species that are grown mainly in developing countries and which have been overlooked by biotechnology R\&D so far.

The introduction of GM technologies and the associated TRIPS regime has been perceived by farmers and others in the rural community, as well as some academics, to threaten the local system of diversity management and decentralised seed distribution by commercialising crop improvements and seed distribution. Within India there has been a long history of openness in India's seed breeding and distribution. The result of these practices has been that the production and dissemination of seeds and crop varieties, even HYV seeds (which preceded the IPR regime for agriculture), have remained highly decentralised. So-called landraces (varieties bred and improved in the field by farmers) have been the basis for the supply of quality seeds in India throughout time. This not only ensures that local communities have had a continuous supply of seeds in a range of varieties, but also that farmers had expert knowledge and understanding of the varieties they produced and the quality of their stock ${ }^{169}$. Furthermore, sacred groves maintained by local tribal populations throughout India provide reservoirs of biodiversity. These were believed to be presided over by various deities and provided long-term insurance against the decline in species and genetic diversity. Improvements in the performance of these landraces, therefore, have historically been public goods in the rural Indian communities.

The way in which the Indian government has aligned itself with the new requirements of the WTO TRIPS agreement is unique and reflects the pre-IPR culture of public seed sharing and maintenance of genetic diversity of agricultural crops ${ }^{170}$. The protection of intellectual property was established with the adoption of the Indian Plant Act in 2001, which combined features of the International UPOV and TRIPS guidelines ${ }^{171}$. However, it also includes many unique features ${ }^{172}$. In particular plant variety protection is extended to extant varieties that are already commonly

\footnotetext{
169 Sahai, "Indigenous Knowledge and Its Protection in India."

170 Lalitha, "Diffusion of Agricultural Biotechnology and Intellectual Property Rights: Emerging Issues in India.", Sahai, "Indigenous Knowledge and Its Protection in India."

${ }^{171}$ Lalitha, "Diffusion of Agricultural Biotechnology and Intellectual Property Rights: Emerging Issues in India."

172 Silvia Salazar, "The World of Biotechnology Patents," Trading in knowledge: development perspectives on TRIPS, trade, and sustainability (2003).
} 
available within the Indian public domain. These include farmer varieties that have traditionally been cultivated and saved by farmers, thereby acknowledging their preference for versatility and adaptability of crop varieties, and the common knowledge of the rural community ${ }^{173}$.

Even more notable is the inclusion of unique farmers' privileges in the Act. This was described in the Indian Plant Varieties and Farmers' Rights Bill (IPVFRB) as the right to:

"save, use, sow, resow, exchange, share or sell his farm produce including seed of a variety protected under this Act in the same manner as he was entitled before the coming into force of this $\mathrm{Act}^{\prime 174}$.

This indicates that while the processes and seeds associated with genetic engineering in the West have been adopted by Indian scientists and farmers, their associated meaning held within some sections of the Indian government and the general population were as public goods rather than private property. This is evidenced in the large proportion of government run biotechnology institutes as well as the farmer privileges recounted in the IPVFRB. These developments cannot simply be explained as the replacement of local seed management systems by the international IPR regime. Nor do GM crops exist in a regime that is separate from landraces. Instead, the Indian IPR regime governing crop varieties has become hybridized such that the commercial and public breeding systems have been incorporated within the IPVFRB. Thus, both landraces and commercial varieties are given plant variety protection, and both local improvements and GM varieties are protected therein.

The addition of farmers' privileges within the Indian Plant Act, constituted this as an example of synthesis rather than additive hybridisation. These privileges represent a novel emergent outcome from the interaction between the international IPR regime's plant variety protection and the decentralised nature of crop improvement and diffusion in Indian agriculture.

$\overline{173}$ Lalitha, "Diffusion of Agricultural Biotechnology and Intellectual Property Rights: Emerging Issues in India."

174 Ibid. p. 194 


\subsection{Summary}

This chapter has provided empirical evidence for technology translation and synthesis within the context of Indian agriculture. Evidence for technology translation comprised the creation of localised meanings for imported technologies, whereas for synthesis this required the existence of emergent and unpredictable outcomes. Indian farmers were found to only selectively adopt available Western technologies during three different historical periods. High rates of cross-cultural technology diffusion were documented during the British colonial era of the 1800s and 1900s, the Green Revolution in the mid-1900s and the current Gene Revolution. In all three stages the imported technologies were imbued with new, socially constructed meanings within Indian society.

Two case studies provided evidence for synthesis between the interacting Indian and Western cultures. The first case study showed that the interaction between Green Revolution technologies and the concept of humoral agronomy led to emergent social outcomes at a grassroots level due to the association with the constitution of a crop and human and societal wellbeing. The second case study showed hybridisation at the level of government policy with the adoption of the Indian Plant Varieties and Farmers' Rights Bill, which resulted in the unique Bill of farmers' privileges that override aspects of the IPR regime itself. This represents a synthesis between the international IPR regimes and local perspectives on ownership of genetic resources. 


\section{CONCLUSIONS}

The case studies in chapter 4 demonstrate technological translation occurring through a process of cultural synthesis in Indian agriculture. At the grassroots level, the adoption of Green Revolution HYV and chemical inputs in Indian food production has resulted in the establishment of new explanations for social trends, new norms for determining social differences, and a recasting of the social and ritual uses of a variety of food products. These outcomes cannot be wholly explained with reference to either the recipient or donor cultures. Rather, the complexities of such cultural change only become explicable when viewed as a non-additive synthesis of these cultures, which gave rise to an emergent, irreversible reality.

Whereas Green Revolution technologies have been widely adopted by Indian farmers, GM technologies are still being negotiated within the Indian administration and remain subject to political considerations. Indeed, the relative novelty of GM technologies in Indian agriculture mean that its adoption by and interaction with Indian farmers is not well examined. This precluded an analysis of grassroots level synthesis like that examined for Green Revolution technologies. Nonetheless, examining the GM related policy decisions made by the Indian politicians revealed that synthesis had also occurred at the level of national government. In this case the Indian government weighed up local cultural realities against international political and economic pressures and responsibilities. A novel set of legal entitlements that benefited farmers were implemented, that drew upon both the IPR regime and the decentralised cultivation and public seed distribution practices. In doing so, the Indian government showed itself to be arguably even more considered about the cumulative effects of the introduction of new technologies and self aware of the collective Indian culture than did the individual farmer.

The purpose of these case studies is to provide an empirical grounding for the translation processes that result from and influence the adoption of non-local technologies. These are typically overlooked by the agents of development who subscribe to a deterministic view of social change. Rather than being linear and predictable, however, I argue that the interactions of local and non-local cultures result in a multitude of possible trajectories which are unpredictable and culturally contingent. This is the essential feature of synthesis: it is unpredictable because what is produced 
is not an a priori property of either culture, it is a unique product that from their interaction.

The adoption of Western technologies does not, therefore, necessarily lead to the adoption of Western values, organisational structures, processes and social relations. The concept of synthesis requires that cultures, both Western and non-Western are capable of change, but not that they uncritically adopt all non-local technologies that are offered. Rather, it suggests that adopted technologies must be given relevance within their new cultural context, providing non-Western societies a degree of agency that is often overlooked. This agency is tempered by unequal power relations between non-Western and Western groups, be they between farmers and development agencies or large biotechnology companies, or non-Western and Western governments. Yet, as the second case study showed, cultural synthesis can take place even in situations where there is tremendous pressure to conform to the wishes of more powerful groups.

Unequal power relations have also helped to create the meanings that some Western technologies have taken in non-Western cultures. The adoption of Western technologies can be a symbol of oppression, but also of peoples' ability to break free from traditional power relationships. What is important, however, is that recipient cultures relate differently to the technology than their donor cultures. While technologies have inherent properties (i.e., tractors will always need petrol to run), the meanings that technologies are imbued with are ultimately derived both from the cultural context in which they are embedded and from how their adoption took place. When seeing technology as a social construction, the meaning it takes provides part of its definition. It then becomes apparent that in the cross-cultural dissemination of technology, new technologies are necessarily created as novel meanings are attached to them. This process is referred to in this thesis as technology translation and offers a critique of, and suggests a replacement for, the common development concept of technology transfer.

Adopting the concept of technology translation draws specific attention to the malleability of technology. This is a property that is not perceived by the development project which maintains a static and culturally neutral definition of technology. This is due to the historic 
association between Western science - which is equated with the pursuit of objective and universal reason and is considered the only valid source of knowledge - and Western technology. This view serves to justify the development project's intervention in so-called developing states. What they purport to offer is a rationally superior version of the technologies of their non-Western counterparts. Hence, the introduction of Western technology in the mainstream development perspective means to leap-frog states up the development ladder.

Similarly, though forming the opposing normative stance, critics of the development project often adopt the same conceptual framework of technology. Critics, such as those who suggest that the diffusion of Western technology in the guise of the development project constitutes a form of cultural imperialism, often argue that the adoption of Western technology supplants the pre-existing practices and erodes non-Western culture. These critics, therefore, also adopt a deterministic view of social change resulting from the adoption of Western technology, thus denying the agency and resilience of local cultures.

Such frameworks leave both the development discourse and many of its critics blind to the conceptual difficulties that surround the nature of technology and its role in social change. These difficulties have, however, been addressed in the literature produced by philosophers of technology. These two fields have, so far, remained stubbornly separate, hindering both the supporters and critics of the development project from reaching an important middle ground where the agency of the recipient society is acknowledged and the mainstream development model takes on a nondeterministic, culturally pluralistic form.

\subsection{Future work}

As has been demonstrated in this thesis, the development discourse needs to be reconciled with the philosophy of technology literature in order to overcome its current conceptual vacuum. The conceptual roots of the development discourse require re-examination. In lieu of such reviews, I suggest a number of other steps which would help bridge the gap between the development and the philosophy of technology discourses.

Firstly, it is necessary to address the dearth of technology adoption studies which focus upon cultural influences in the adoption process, and 


\section{Conclusion}

which do so in what the social constructivists term a symmetrical manner. This means that scientific or economic rationality must not be assumed to be without a basis in culture. Such studies would identify the meanings the rejected as well as adopted technologies are imbued with. This will provide a more balanced account of the factors influencing the cross-cultural diffusion of technology.

Secondly, the influence of non-Western cultures and technology diffusion has had upon the West remains to be examined. Western culture is undoubtedly also hybridised and should not be considered monolithic and only changed by the force of its own innovation. It too is impacted both as the donor and recipient in cross cultural technology diffusion. At the time of writing, however, I have not been able to locate a single study that addressed this aspect of Western cultural and technological change.

Finally, a study area with growing relevance is the hybrid nature of GM technologies developed by non-Western actors within non-Western states. As noted earlier, India has become a producer of biotechnology in its own right, but whether this biotechnology bears evidence of its hybrid nature also remains unexamined to date. 
References

\section{REFERENCES}

Adas, M. "A Field Matures: Technology, Science, and Western Colonialism." Technology and Culture 38, no. 2 (1997): 478-87.

Alvarez, MR. "Modern Technology and Technological Determinism: The Empire Strikes Again." Bulletin of Science, Technology \& Society 19, no. 5 (1999): 403.

Anderson, RS, and BM Morrison. "Science, Politics, and the Agricultural Revolution in Asia." Paper presented at the AAAS Selected Symposium, San Francisco, 1982.

Anderson, W. "Introduction: Postcolonial Technoscience." Social studies of Science (2002): 643-58.

Anonymous. "India Puts on Hold First Gm Food Crop on Safety Grounds " BBC News online at http://news.bbc.co.uk/2/hi/8506047.stm, 09.02.2010

Appadurai, A. "The Production of Locality." Counterworks: Managing the diversity of knowledge (1995): 204-23.

Bebbington, A. "Indigenous Agricultural Knowledge Systems, Human Interests, and Critical Analysis: Reflections on Farmer Organization in Ecuador." Agriculture and Human Values 8, no. 1 (1991): 14-24.

Brodt, S. "Learning About Tree Management in Rural Central India: A LocalGlobal Continuum." Human organization 61, no. 1 (2002): 58-67.

Brodt, SB. "Interactions of Formal and Informal Knowledge Systems in Village-Based Tree Management in Central India." Agriculture and Human Values 16, no. 4 (1999): 355-63.

Buckley, W. Sociology and Modern Systems Theory: Prentice-Hall Englewood Cliffs, NJ, 1967.

Bunge, M. "Technology as Applied Science." Technology and Culture 7, no. 3 (1966): 329-47.

Chakrabarty, D. Provincializing Europe: Postcolonial Thought and Historical Difference: Princeton Univ Pr, 2000.

Chambers, R. Rural Development: Putting the Last First: Longman London, 1999.

Cohen, Jl, and R Paarlberg. "Unlocking Crop Biotechnology in Developing Countries--a Report from the Field." World Development 32, no. 9 (2004): 1563-77.

Cooper, F. "Conflict and Connection: Rethinking Colonial African History." The American Historical Review 99, no. 5 (1994): 1516-45.

Dessauer, F. "Technology in Its Proper Sphere." Philosophy and Technology: 317-34.

Dunch, R. "Beyond Cultural Imperialism: Cultural Theory, Christian Missions, and Global Modernity." History and Theory 41, no. 3 (2002): 301-25.

Dusek, V. Philosophy of Technology: An Introduction: Blackwell Pub, 2006.

Ellul, J. The Technological Society: Knopf Books for Young Readers, 1964.

Ellul, J, and J Neugroschel. The Technological System: Citeseer, 1980. 
Escobar, A. "Whose Knowledge, Whose Nature? Biodiversity, Conservation, and the Political Ecology of Social Movements." Journal of Political Ecology 5, no. 1 (1998): 53-82.

Escobar, Arturo. "The Making and Unmaking of the Third World through Development." In The Post-Development Reader, edited by M Rahnema and V Bawtree: Zed Books London, 1998.

FAO. "Biotechnologies in Developing Countries: India." FAO, http://www.fao.org/biotech/inventory_admin/dep/default.asp.

\section{- - " "Technology for Agriculture (Online)." \\ http://www.fao.org/teca/content/terms-dictionaries-and-fao- publications.}

Feenberg, A. Critical Theory of Technology: Oxford University Press New York, NY, 1991.

Franssen, Maarten, Gert-Jan Lokhorst, and Ibo van de Poel. "Stanford Encyclopedia of Philosophy: Technology (Online) at Http://Plato.Stanford.Edu/Entries/Technology/ ".

Giere, RN. Scientific Perspectivism: University of Chicago Press, 2006.

Gupta, A. Postcolonial Developments: Agriculture in the Making of Modern India: Duke Univ Pr, 1998.

Hacking, I. "How Inevitable Are the Results of Successful Science?" Philosophy of Science 67, no. 3 (2000): 58-71.

_-_. "The Self-Vindication of the Laboratory Sciences." Science as practice and culture 65, (1992).

-_- The Social Construction of What?: Harvard Univ $\operatorname{Pr}, 1999$.

Hannerz, U. Cultural Complexity: Studies in the Social Organization of Meaning: Columbia Univ Pr, 1992.

Harding, SG. Is Science Multicultural?: Postcolonialisms, Feminisms, and Epistemologies: Indiana Univ Pr, 1998.

Hindmarsh, R. "Genetic Modification and the Doubly Green Revolution." Society 40, no. 6 (2003): 9-19.

Hirschman, AO. "The Rise and Decline of Development Economics." Essays in Trespassing: Economics to Politics and Beyond 1, (1981): 24.

Hooke, RLB. "On the History of Humans as Geomorphic Agents." Geology 28, no. 9 (2000): 843.

House, RJ, G Leadership, PJ Hanges, M Javidan, PW Dorfman, and V Gupta. Culture, Leadership, and Organizations: The Globe Study of 62 Societies: Sage Pubns, 2004.

Ingold, Tim. "Chapter 2: The Optimal Forager and Economic Man." In Nature and Society: Anthropological Perspectives, edited by P Descola and G Pálsson. London \& New York: Routledge, 1996.

Jonas, H. "Toward a Philosophy of Technology." The Hastings Center Report 9, no. 1 (1979): 34-43.

Kline, R. "Construing" Technology" As" Applied Science": Public Rhetoric of Scientists and Engineers in the United States, 1880-1945." Isis 86, no. 2 (1995): 194-221. 
References

Kok, Esther J., and Harry A. Kuiper. "Comparative Safety Assessment for Biotech Crops." Trends in Biotechnology 21, no. 10 (2003): 439-44.

Kurin, R. "Indigenous Agronomics and Agricultural Development in the Indus Basin." Human organization 42, no. 4 (1983): 283-94.

Lalitha, N. "Diffusion of Agricultural Biotechnology and Intellectual Property Rights: Emerging Issues in India." Ecological Economics 49, no. 2 (2004): 187-98.

MacLeod, RM, and D Kumar. Technology and the Raj: Western Technology and Technical Transfers to India, 1700-1947: Sage Publications Pvt. Ltd, 1995.

Matuschke, I, RR Mishra, and M Qaim. "Adoption and Impact of Hybrid Wheat in India." World Development 35, no. 8 (2007): 1422-35.

Mauro, Francesco, and D. Hardison Preston. "Traditional Knowledge of Indigenous and Local Communities: International Debate and Policy Initiatives." Ecological Applications 10, no. 5 (2000): 1263-69.

Ministry of Environment \& Forests. "Regulatory Reforms in Biotechnology Article 4." Department of Biotechnology, Ministry of Science and Technology, http://dbtindia.nic.in/uniquepage.asp?id_pk=112.

Mitcham, C. Thinking through Technology: The Path between Engineering and Philosophy: University of Chicago Press, 1994.

Morowitz, HJ. The Emergence of Everything: How the World Became Complex. New York: Oxford University Press 2002.

Mumford, L. The Myth of the Machine: Technics and Human Development: Harcourt Brace Jovanovich, 1967.

Murray, WE. Geographies of Globalization: Routledge, 2006.

Nandy, A. Traditions, Tyranny, and Utopias: Essays in the Politics of Awareness: Oxford University Press, USA, 1987.

Netting, RMC. Smallholders, Householders: Farm Families and the Ecology of Intensive, Sustainable Agriculture: Stanford Univ Pr, 1993.

Pacey, A. The Culture of Technology: The MIT Press, 1983.

Padma, T.V. "India Says No - for Now - to First Gm Vegetable." Science and Development Network online at http://www.scidev.net/en/news/india-says-no-for-now-to-first-gmvegetable.html, 09.02.2010.

Parayil, Govindan. "Mapping Technological Trajectories of the Green Revolution and the Gene Revolution from Modernization to Globalization." Research Policy 32, no. 6 (2003): 971-90.

Pickering, A. "From Science as Knowledge to Science as Practice." Science as practice and culture (1992): 1-26.

Pieterse, JN. "After Post-Development." Third World Quarterly 21, no. 2 (2000): 175-91.

Pinch, TJ, and WE Bijker. "The Social Construction of Facts and Artefacts: Or How the Sociology of Science and the Sociology of Technology Might Benefit Each Other." Social studies of Science 14, no. 3 (1984): 399441. 
Popper, KR. The Logic of Scientific Discovery: Hutchinson, 1959.

Popper, KR, and P Camiller. All Life Is Problem Solving: Routledge, 1999.

Rao, P Rama. "India: Science and Technology from Ancient Time to Today." Technology in Society 19, no. 3-4 (1997): 415-47.

Rist, G. The History of Development: From Western Origins to Global Faith: Zed Books, 2002.

Rivers, TJ. "An Introduction to the Metaphysics of Technology." Technology in Society 27, no. 4 (2005): 551-74.

Sahai, S. "Indigenous Knowledge and Its Protection in India." Trading in knowledge: development perspectives on TRIPS, trade, and sustainability (2003): 166.

Salazar, Silvia. "The World of Biotechnology Patents." Trading in knowledge: development perspectives on TRIPS, trade, and sustainability (2003): 117-26.

Sangwan, Saptal. "Level of Agricultural Technology in India (1757-1857)." Asian Agri-History 11, no. 1 (2007): 5-25.

Scharff, RC, and V Dusek. Philosophy of Technology: The Technological Condition: An Anthology: Blackwell, 2003.

Senarclens, Pierre de. "How the United Nations Promotes Development through Technical Assistance." In The Post-Development Reader, edited by M Rahnema and V Bawtree: Zed Books London, 1998.

Shanin, Teodor. "The Idea of Progress." In The Post-Development Reader, edited by M Rahnema and V Bawtree: Zed Books London, 1998.

Shiva, V. "The Future of Food: Countering Globalisation and Recolonisation of Indian Agriculture." Futures 36, no. 6-7 (2004): 715-32.

- - Monocultures of the Mind: Third World Network, 1993.

Slack, JD, and JM Wise. Culture + Technology: A Primer. New York: Peter Lang, 2005.

Smith, GB. "Heidegger, Technology and Postmodernity." The Social Science Journal 28, no. 3 (1991): 369-89.

Smith, RJ. "Sustainability and the Rationalisation of the Environment." Environmental Politics 5, no. 1 (1996): 25-47.

Soler, L. "Are the Results of Our Science Contingent or Inevitable?" Studies in History and Philosophy of Science (2008).

Srinivas, MN. "Caste in Modern India." The Journal of Asian Studies 16, no. 4 (1957): 529-48.

Steers, Richard M, Alan D Meyer, and CJ Sanchez-Runde. "National Culture and the Adoption of New Technologies." Journal of world business 43, no. 3 (2008).

Vasavi, AR. "'Hybrid Times, Hybrid People': Culture and Agriculture in South India." Man (1994): 283-300.

Winner, Langdon. "Technologies as Forms of Life." In Readings in the Philosophy of Technology, edited by DM Kaplan: Rowman \& Littlefield, 2004. 
References

Wolpert, SA. A New History of India: Oxford University Press, USA, 2004.

WTO. "Intellectual Property: Protection and Enforcement." WTO, http://www.wto.org/english/thewto_e/whatis_e/tif_e/agrm7_e.htm.

Zaid, A, HG Hughes, E Porceddu, and F Nicholas. Glossary of Biotechnology and Genetic Engineering. Edited by FAO, Fao Research and Technology Papers - 7. Rome: FAO, 1999 
Appendix

\section{APPENDIX - LIST OF ABBREVIATIONS}

Bt - Bacillus thuringiensis

CGIAR - Consultative Group on International Agricultural Research

ECOSOC - Economic and Social Council

EPT - Engineering Philosophy of Technology

FAO - Food and Agricultural Organisation

GEAC - Genetic Engineering Approval Committee

GM - Genetically Modified

GR - Green Revolution

HPT - Humanities Philosophy of Technology

HYV - High Yielding Varieties

IPR - Intellectual Property Rights

IPVFRB - Indian Plant Varieties and Farmers' Rights Bill

NGO - Non-Governmental Organisation

UPOV - Protection of New Varieties of Plants

TRIPS -Trade-Related Aspects of Intellectual Property Rights

PL 480 - U.S. Public Law 480.

UN - United Nations

WTO - World Trade Organisation 